University of Wollongong

Research Online

Faculty of Engineering and Information

Faculty of Engineering and Information

Sciences - Papers: Part B

Sciences

2019

A review of heating, ventilation and air conditioning technologies and innovations used in solar-powered net zero energy Solar Decathlon houses

Zhenjun Ma

University of Wollongong, zhenjun@uow.edu.au

Haoshan Ren

University of Wollongong, hr681@uowmail.edu.au

Wenye Lin

University of Wollongong, wenye@uow.edu.au

Follow this and additional works at: https://ro.uow.edu.au/eispapers1

Part of the Engineering Commons, and the Science and Technology Studies Commons

Research Online is the open access institutional repository for the University of Wollongong. For further information contact the UOW Library: research-pubs@uow.edu.au 


\title{
A review of heating, ventilation and air conditioning technologies and innovations used in solar-powered net zero energy Solar Decathlon houses
}

\author{
Abstract \\ Innovations in Heating, Ventilation, and Air Conditioning (HVAC) systems are continuously required to \\ provide a better, healthier and more productive and sustainable built environment for building occupants \\ with minimized energy or cost consumption. This paper provides an overview of the HVAC technologies \\ and systems used in 212 solar-powered houses developed through 13 U.S. Department of Energy Solar \\ Decathlon (SD) competitions. Some comments and discussions on the HVAC technologies and systems \\ used in the SD competitions were also provided. The review was carried out based on the information \\ available from the organizer's project reports and equipment summary, team project manuals, and \\ construction drawings available on the SD official websites as well as the published research papers and \\ textbooks. It was found that $84.9 \%$ and $89.6 \%$ of the competition teams used heat pumps for space \\ heating and space cooling, respectively, among which air-to-air heat pumps were used by approximately \\ $50 \%$ of the competition teams. A wide range of energy technologies such as phase change materials, \\ night-time radiative cooling, evaporative cooling, desiccant dehumidification, and energy/heat recovery \\ ventilators have been used to reduce the electricity consumption of the HVAC systems. Energy/heat \\ recovery ventilators were used by more than $55 \%$ of the teams in each competition held after 2005 . Phase \\ change materials were also frequently used in the competitions held in Europe. The SD competitions \\ provided an excellent platform to showcase innovations of the HVAC technologies in residential \\ buildings. \\ Disciplines \\ Engineering | Science and Technology Studies

\section{Publication Details} \\ Ma, Z., Ren, H. \& Lin, W. (2019). A review of heating, ventilation and air conditioning technologies and \\ innovations used in solar-powered net zero energy Solar Decathlon houses. Journal of Cleaner \\ Production, 240 118158-1-118158-17.
}


Amount of words: 11,162

\title{
A review of Heating, Ventilation and Air Conditioning technologies and innovations used in solar-powered net zero energy Solar Decathlon houses
}

5

\author{
Zhenjun Ma*, Haoshan Ren*, Wenye Lin
}

\author{
Sustainable Buildings Research Centre, University of Wollongong, 2522, Australia \\ *zhenjun@uow.edu.au (Zhenjun Ma); hr681@uowmail.edu.au (Haoshan Ren)
}

Abstract: Innovations in Heating, Ventilation, and Air Conditioning (HVAC) systems are

continuously required to provide a better, healthier and more productive and sustainable built

environment for building occupants with minimized energy or cost consumption. This paper

provides an overview of the HVAC technologies and systems used in 212 solar-powered houses

developed through 13 U.S. Department of Energy Solar Decathlon (SD) competitions. Some

comments and discussions on the HVAC technologies and systems used in the SD competitions

were also provided. The review was carried out based on the information available from the organizer’s project reports and equipment summary, team project manuals, and construction drawings available on the SD official websites as well as the published research papers and textbooks. It was found that $84.9 \%$ and $89.6 \%$ of the competition teams used heat pumps for space heating and space cooling, respectively, among which air-to-air heat pumps were used by approximately $50 \%$ of the competition teams. A wide range of energy technologies such as phase change materials, night-time radiative cooling, evaporative cooling, desiccant dehumidification, and energy/heat recovery ventilators have been used to reduce the electricity 
22 consumption of the HVAC systems. Energy/heat recovery ventilators were used by more than

$2355 \%$ of the teams in each competition held after 2005. Phase change materials were also

24 frequently used in the competitions held in Europe. The SD competitions provided an excellent

25 platform to showcase innovations of the HVAC technologies in residential buildings.

26 Keywords: Net zero energy; HVAC; Solar Decathlon; Innovations; Renewable energy

27 Abbreviations

28 DW desiccant wheel

29 ERV energy recovery ventilator

30 GSHP ground source heat pump

31 HRV heat recovery ventilator

32 HTF heat transfer fluid

33 HVAC heating, ventilation and air conditioning

34 LAC Latin America and Caribbean

35 LD liquid desiccant

36 ME Middle East

$37 \quad$ PCM phase change material

38 PVT photovoltaic-thermal

39 SD Solar Decathlon

40 TES thermal energy storage

41 

consumers in buildings and responsible for about 50\% of total building energy consumption (Chua et al., 2013; Pérez-Lombard et al., 2008). HVAC systems are one of the main contributors to the peak demand of electric grids (Desideri, 2009) and are becoming increasingly important in the maintenance of the quality of life for a large fraction of the world's population. The number of HVAC systems installed is expected to dramatically increase in the coming decades, largely driven by economic growth, global warming and improvement in the living standards (Isaac and van Vuuren, 2009; Pérez-Lombard et al., 2008). It is estimated that the world electricity consumption of the HVAC systems will increase by a factor of 33 by the end of the century (Axell, 2015). On the other hand, there is long-standing and comprehensive evidence that HVAC systems have a direct effect on health, wellbeing, and productivity of building occupants. Low carbon and healthy HVAC systems are therefore essential to reducing global energy usage and greenhouse gas emissions, mitigating climate change, and maintaining satisfied indoor environment.

Over the last several decades, numerous innovations have been made on the development of innovative HVAC technologies. For instance, desiccant cooling has gained significant

59 scientific attention due to its potential to achieve energy savings in tropical and subtropical 60 regions (Ren et al., 2019a; Sahlot and Riffat, 2016). Thermal energy storage (TES) using phase

61 change materials (PCMs) as an integrated component of HVAC systems has been investigated

62 for effective peak demand control and load shifting (Cui et al., 2015; Sun et al., 2013). There has been a great initiative to take HVAC off the gird by developing solar thermal driven HVAC 
technologies and stand-alone solar-powered HVAC systems (Al-Alili et al., 2014; Huang et al., 2016). Solar assisted ground source heat pump (GSHP) systems and deep borehole GSHP systems are being examined, aiming to improve long-term heat transfer performance of ground heat exchangers and provide energy efficient heating and cooling (Wang et al., 2017; Xia et al., 2018). Heat and energy recovery ventilators were also extensively studied to assist in achieving energy savings (Mardiana-Idayu and Riffat, 2012).

Great efforts have also been made on the development of advanced design and control strategies for building HVAC systems to achieve enhanced energy or cost savings (Huang et al., 2015; Wang and Ma, 2008). The optimal solutions were generally determined based on one or multiple objectives such as energy performance, thermal performance, environmental performance and economic performance (Huang et al., 2015). Both the model-based approach and model-free approach have been used to formulate design and control optimization problems for HVAC systems. For instance, a model-based strategy using genetic algorithms was developed to optimally design active cooling energy storage units integrated with the HVAC systems for demand-side management of commercial buildings (Cui et al., 2017). A multi-objective design optimization strategy for vertical ground heat exchangers was developed to minimize the system upfront cost and entropy generation number (Huang et al., 2015). Adhikari et al. (2018) presented an optimal control method that uses a combination of a greedy algorithm and a binary search algorithm for a population of HVAC units to optimize the aggregated power demand. A self-optimization strategy with extremum seeking control was employed to achieve energy efficient control of a hybrid GSHP system (Hu et al., 2016). The 
model-based control strategies with and without learning and predictive functions have been extensively studied and used to search for the most energy efficient control settings for HVAC systems under ever-changing working conditions (Afram and Janabi-Sharifi, 2014; Ma and Wang, 2011). The results from these studies showed that optimization can play an essential role in ensuring that HVAC systems can deliver a healthy and productive built environment with minimized energy or cost consumption.

Innovations and breakthroughs in HVAC systems are continuously required. The U.S. Department of Energy Solar Decathlon (SD) is a great initiative and a live demonstration of the latest innovations in technologies, materials, and solutions developed for sustainable buildings (Solar Decathlon US, 2017). The buildings developed by the SD teams are generally single-family detached houses. More than 200 solar-power houses which aimed to achieve comfortable indoor environment and net-zero energy consumption have been developed and built through the SD competitions and a wide range of innovative HVAC technologies have been used in these houses. However, the HVAC technologies and HVAC innovations used in these SD houses have not been reviewed in the previous studies.

This paper aims to provide an overview of main HVAC technologies and systems developed and used in the previous Solar Decathlon competitions to demonstrate evidence-based HVAC

102 innovations. The organization of this paper is as follows. Section 2 provides a brief introduction 103 to the Solar Decathlon competition and thermal comfort contest. Section 3 presents a statistical 104 analysis of major HVAC technologies used in the previous SD competitions. In Section 4, the major HVAC technologies and systems used in the previous SD competitions are reviewed, 
discussed and summarized. Some conclusive remarks are provided in Section 5.

\section{Introduction to the Solar Decathlon competition}

111 US, 2017). Fig. 1 presents an example of the Solar Decathlon competition held in the SD China

1122013 competition. Like the Olympic decathlon, the Solar Decathlon competition consists of

113 ten contests. The ten contests used in the Solar Decathlon Middle East 2018 consisted of

114 architecture, engineering and construction, energy efficiency, sustainability, communication, innovation, energy management, comfort conditions, house functioning, and sustainable transportation (Solar Decathlon Middle East, 2018).

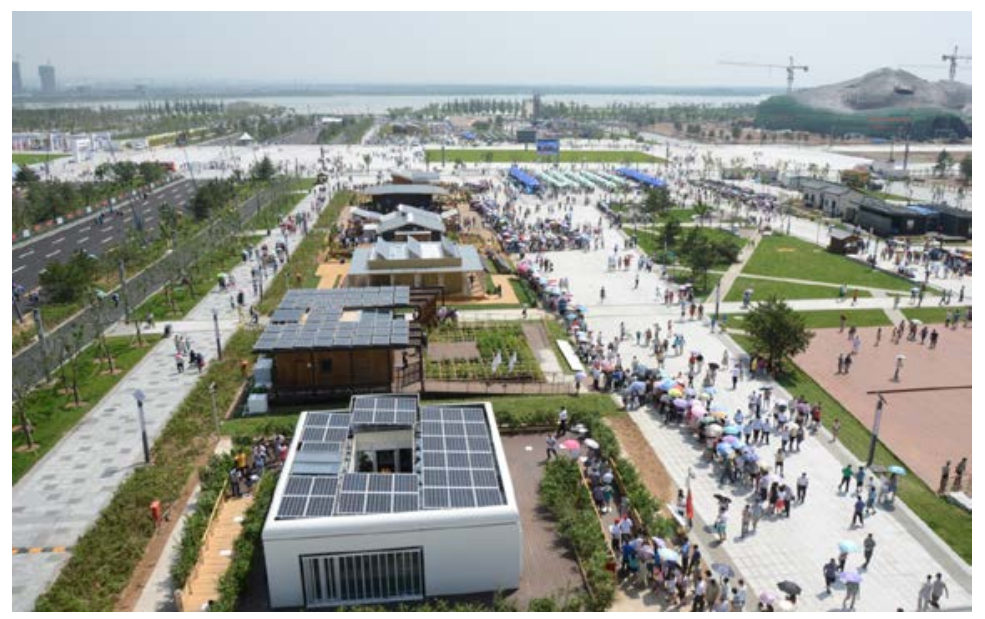

118 Fig. 1. An example of the competition in the Solar Decathlon China 2013 competition. competitions and the countries and locations where the competitions were held, as well as the number of the teams participated in each competition (see the number in the bracket). It is noted that some competition teams were formed with more than one university. To date, there were 


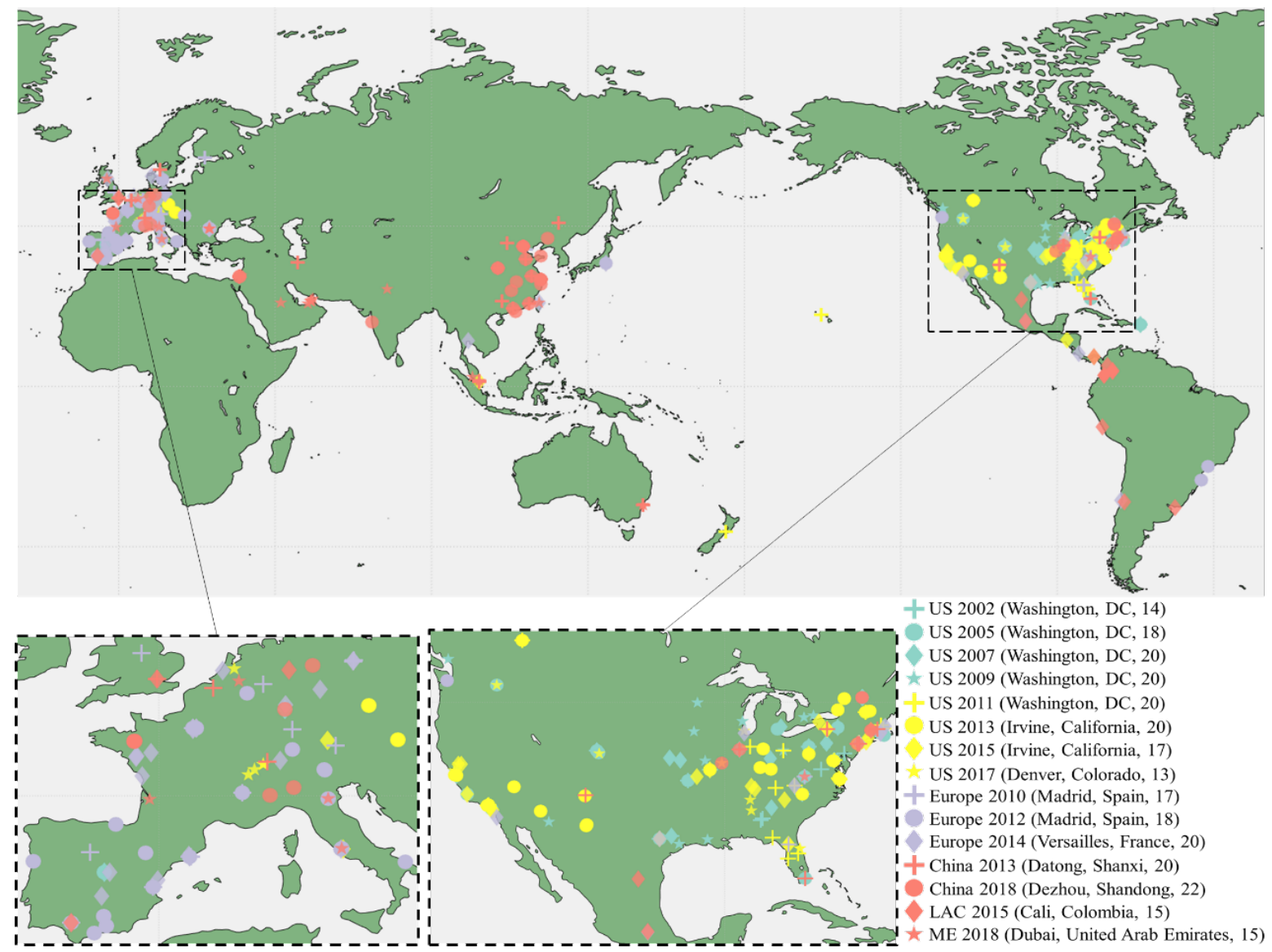

Fig. 2. Illustration of the locations of the universities participated in the previous SD 
consisted of six sub-contests including temperature, humidity, air quality, lighting, façade

136 airborne sound insulation, and HVAC noise (Solar Decathlon Middle East, 2018). According

137 to the competitions rules, full points can be obtained if the teams can maintain their indoor

138 conditions within the required ranges, and no point will be awarded if the indoor conditions

139 were above or below certain values. Otherwise, a reduced point can be obtained.

140 3. Statistical analysis of the HVAC technologies used in the previous SD competitions

1413.1 Methodology of the review

142 In this section, the HVAC systems and technologies used in the teams participated in the

143 previous SD competitions were analyzed. The analysis was performed based on the information

144 available from the organizer's project reports and equipment summary, team project manuals,

145 and construction drawings available on the SD official websites as well as the published

146 research papers and textbooks. It is noteworthy that the HVAC systems used in 13 competition

147 teams were not reviewed due to lack of the information available and it is not our intention to

148 miss the HVAC system used by a particular team. It is also worthwhile to note that the team

149 names used referred to the names provided on the SD official websites.

150 Due to lack of the information from some competitions and some teams, the HVAC systems

151 used by 212 teams were analyzed herein, including 134 teams from the SD US competitions,

15255 teams from the SD Europe competitions, 10 teams from the SD China 2013 competition,

153 and 13 teams from the SD ME 2018 competition. It is noteworthy that this analysis was

154 developed based on our best understanding of the information provided in the aforementioned

155 literature and the actual systems from some teams built on-site may be slightly different due to 
various reasons. In addition, the teams that withdrew from the competitions and failed to build

157 the house on-site were not analyzed. space cooling in the 212 teams reviewed. The HVAC technologies used for space heating were mainly categorized into three groups including passive heating, solar thermal heating and heat pump dominated heating. Passive heating represents that the space heating was achieved using passive technologies such as daylight control and thermal mass with integrated ventilation systems and did not rely on any active heating devices ((e)co Team, 2012; Team Mexico UNAM, 2014). It is noted that simple passive solar designs such as south-oriented windows and using low-emissivity glasses were not considered as passive technologies in this statistical analysis. Solar thermal heating represents that space heating was achieved by using solar

168 thermal collectors only (Team FENIX, 2014; Team Iowa State, 2009). Heat pump dominated

169 heating represents that space heating was either provided by heat pumps only or jointly

170 provided by heat pumps and solar thermal collectors (Team Ohio State, 2011; Team Prêt-à-

171 Loger, 2014). The HVAC technologies used for space cooling were categorized into passive

172 cooling, absorption/adsorption cooling, and heat pump dominated cooling. Similarly, passive

173 cooling means that space cooling was achieved using passive technologies such as night-time

174 ventilation and natural ventilation ((e)co Team, 2012; Sánchez et al., 2010).

175 Absorption/adsorption cooling means that only absorption or adsorption cooling technologies

176 were used for space cooling (Team Cincinnati, 2007; Team Santa Clara, 2007). Heat pump 
177 dominated cooling represents that space cooling was provided by heat pumps only or jointly

178 provided by heat pumps and other cooling technologies such as evaporative cooling, night-time

179 radiative cooling, desiccant dehumidification, and thermoelectric cooling (Team Alabama,

180 2017; Team TDIS 2018; Fiorentini et al., 2015). It can be seen that heat pumps were used by

181 the majority of the competition teams for both space heating and space cooling. Passive heating

182 and solar thermal heating were used by 3 teams (1.4\%) and 24 teams (11.3\%), respectively. 14

183 teams (6.6\%) and 4 teams (1.9\%) used passive cooling and absorption/adsorption cooling for

184 space cooling, respectively.

185

186

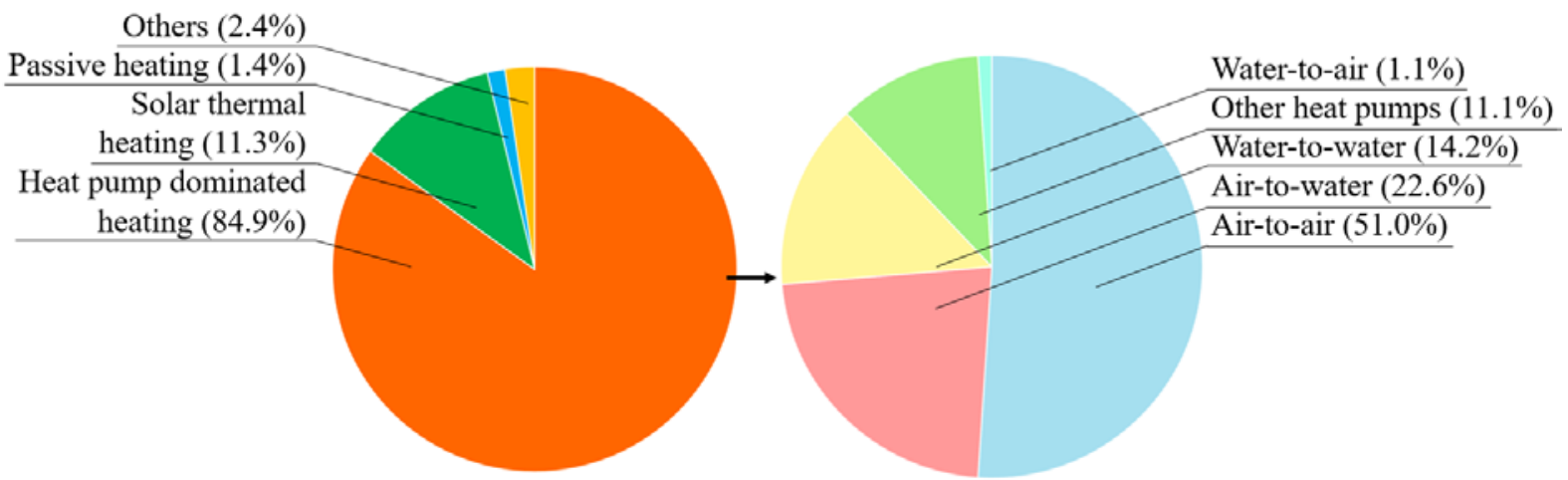

187

a) Space heating

188

189

190 


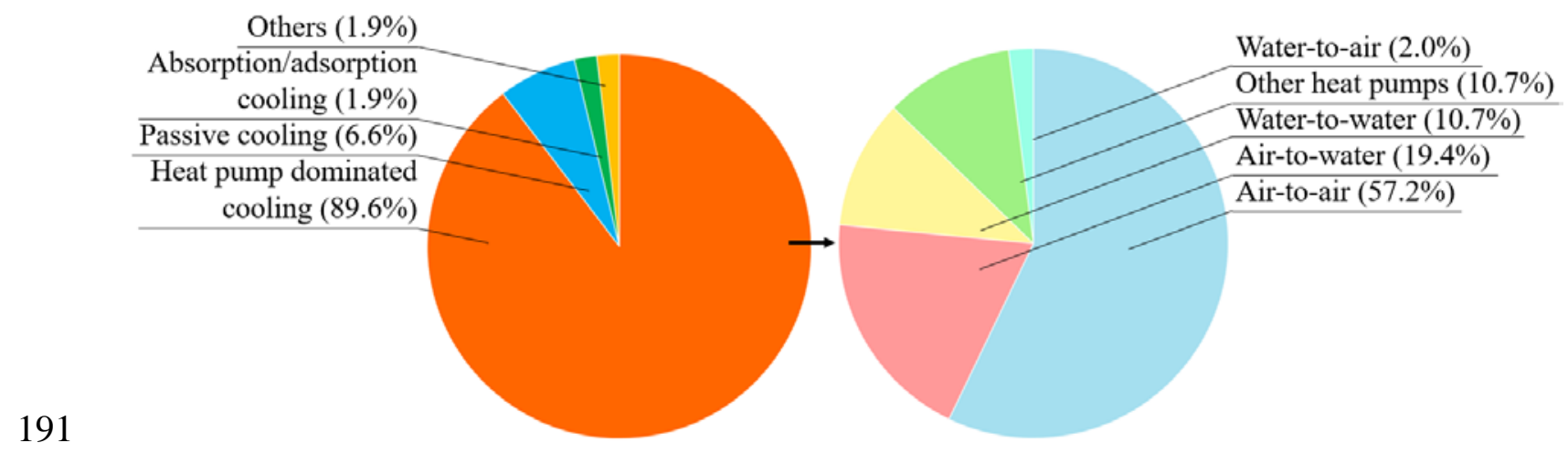

b) Space cooling

Fig. 3. HAVC technologies used in 212 SD competition teams for space heating and space cooling.

A further analysis was carried out for the heat pumps used in the previous SD competitions and the results are also presented in Fig. 3. According to the heat transfer fluids used in the evaporator and condenser, the heat pumps used were categorized into five groups including airto-air heat pumps, air-to-water heat pumps, water-to-water heat pumps, water-to-air heat pumps, and other heat pumps. The heat pumps were mainly categorized based on the heat sink/source used for space cooling and the heat source/sink used for space heating. Other heat pumps mainly included compact heat pumps for both air and water heating at the same time; heat pump water heaters using solar panels as the evaporator; and thermodynamic heat pumps in which the compressor was operated by a thermally driven turbine. pumps, other heat pumps, and water-to-air heat pumps for both space heating and space cooling. air heat pumps, respectively. The percentages of using air-to-water heat pumps and water-to- 
water heat pumps for space heating were slightly higher than those for space cooling. Only a

210 few teams used water-to-air heat pumps for space heating and space cooling. It is worthwhile

211 to note that water-to-water heat pumps and water-to-air heat pumps used by some teams were

212 developed based on the concept of ground source heat pumps, in which ground heat exchangers

213 were emulated by using a water tank (Team Penn State, 2007; Team Virginia Tech, 2009; Team

214 WASH U - ST. LOUIS, 2017) or a phase change material (PCM) thermal energy storage (TES)

215 unit (Sánchez et al., 2010).

216 For the delivering method of the HVAC systems used by the 212 SD houses reviewed, 54.3\%

217 of the teams used air to condition the indoor space through either ducted systems or ductless

218 systems for space heating, and $71.2 \%$ of the teams used air to deliver cooling energy. $15.1 \%$

219 and $6.6 \%$ of the competition teams used radiant panels such as radiant floor, radiant ceiling and

220 hot water radiator for space heating and cooling, respectively. A number of teams used both air

221 and radiant panels for space heating (24.1\%) and cooling (14.6\%), respectively.

222 Heat recovery ventilators (HRVs) and energy recovery ventilators (ERVs) as energy

223 recovery solutions have been frequently used to improve the energy performance of HVAC

224 systems. The HRV and ERV were used to recover the sensible heat and total heat, i.e. sensible

225 heat and latent heat, between the two air flows, respectively. Among the teams used HRVs and

226 ERVs, 63.3\% of the teams used ERVs and the rest used HRVs. HRVs were mostly used in the

227 SD competitions held in Madrid (Spain) and Versailles (France) where weather conditions are

228 moderate, and humidity control was not the major focus in the HVAC system design.

229 3.3 HVAC technologies used in each competition 
231 in each competition were also analyzed. In this section, the HVAC technologies were analyzed

232 based on the technologies used including solar thermal space heating, night-time radiative

233 cooling, evaporative cooling, desiccant dehumidification, and absorption/adsorption cooling as

234 heating/cooling technologies, PCM as energy storage technology, ERV/HRV as recovery

235 ventilators, and radiant heating and radiant cooling as delivering methods. It is noted that the

236 focus of this review was on the technologies used to provide and/or assist space heating,

237 cooling, and ventilation, and domestic hot water was not included in the statistical analysis.

238 The analysis was carried out by determining the percentage of the teams using these

239 technologies to the total number of the teams participated in each competition. The results of

240 the statistical analysis are summarized in Fig. 4. 


\begin{tabular}{|c|c|c|c|c|c|c|c|c|c|}
\hline \multirow[b]{2}{*}{ US 2002} & \multicolumn{4}{|c|}{$\begin{array}{l}\text { Heating/cooling } \\
\text { technologies }\end{array}$} & \multicolumn{2}{|c|}{$\begin{array}{c}\text { Energy storage } \\
\text { technology }\end{array}$} & \multicolumn{2}{|c|}{$\begin{array}{l}\text { Recovery } \\
\text { ventilator }\end{array}$} & $\begin{array}{l}\text { Delivering } \\
\text { methods }\end{array}$ \\
\hline & $53.8 \%$ & $0.0 \%$ & $0.0 \%$ & $7.7 \%$ & $0.0 \%$ & $0.0 \%$ & $15.4 \%$ & $30.8 \%$ & $0.0 \%$ \\
\hline US 2005 & $61.1 \%$ & $5.6 \%$ & $0.0 \%$ & $5.6 \%$ & $0.0 \%$ & $22.2 \%$ & $55.6 \%$ & $50.0 \%$ & $5.6 \%$ \\
\hline US 2007 & $65.0 \%$ & $10.0 \%$ & $0.0 \%$ & $5.0 \%$ & $10.0 \%$ & $20.0 \%$ & $70.0 \%$ & $55.0 \%$ & $10.0 \%$ \\
\hline US 2009 & $55.0 \%$ & $0.0 \%$ & $0.0 \%$ & $10.0 \%$ & $5.0 \%$ & $20.0 \%$ & $80.0 \%$ & $50.0 \%$ & $10.0 \%$ \\
\hline Europe 2010 & $41.2 \%$ & $17.6 \%$ & $29.4 \%$ & $0.0 \%$ & $5.9 \%$ & $52.9 \%$ & $76.5 \%$ & $52.9 \%$ & $58.8 \%$ \\
\hline US 2011 & $31.6 \%$ & $0.0 \%$ & $0.0 \%$ & $15.8 \%$ & $5.3 \%$ & $26.3 \%$ & $78.9 \%$ & $15.8 \%$ & $5.3 \%$ \\
\hline Europe 2012 & $50.0 \%$ & $33.3 \%$ & $22.2 \%$ & $11.1 \%$ & $5.6 \%$ & $44.4 \%$ & $77.8 \%$ & $38.9 \%$ & $33.3 \%$ \\
\hline China 2013 & $40.0 \%$ & $20.0 \%$ & $10.0 \%$ & $10.0 \%$ & $0.0 \%$ & $60.0 \%$ & $70.0 \%$ & $40.0 \%$ & $10.0 \%$ \\
\hline US 2013 & $26.3 \%$ & $5.3 \%$ & $0.0 \%$ & $5.3 \%$ & $0.0 \%$ & $15.8 \%$ & $73.7 \%$ & $36.8 \%$ & $31.6 \%$ \\
\hline Europe 2014 & $65.0 \%$ & $5.0 \%$ & $15.0 \%$ & $10.0 \%$ & $0.0 \%$ & $50.0 \%$ & $90.0 \%$ & $40.0 \%$ & $35.0 \%$ \\
\hline US 2015 & $14.3 \%$ & $7.1 \%$ & $0.0 \%$ & $0.0 \%$ & $0.0 \%$ & $7.1 \%$ & $71.4 \%$ & $21.4 \%$ & $14.3 \%$ \\
\hline US 2017 & $9.1 \%$ & $0.0 \%$ & $9.1 \%$ & $9.1 \%$ & $0.0 \%$ & $9.1 \%$ & $90.9 \%$ & $45.5 \%$ & $18.2 \%$ \\
\hline ME 2018 & $0.0 \%$ & $15.4 \%$ & $7.7 \%$ & $7.7 \%$ & $0.0 \%$ & $23.1 \%$ & $69.2 \%$ & $23.1 \%$ & $38.5 \%$ \\
\hline
\end{tabular}

Fig. 4. Statistical analysis of the HVAC technologies used in each SD competition.

248 thermal for space heating increased from $41.2 \%$ in 2010 to $65.0 \%$ in 2014 . No team used solar

249 thermal for space heating in the SD ME 2018 competition. The night-time radiative cooling

250 was first used in the US 2005 competition and only a few teams used this technology in the SD

251 US competitions. However, one-third of the teams used night-time radiative cooling in the SD

252 Europe 2012 competition. The data from the more recent competitions (i.e. US 2015 and US 
254 limited, although there were two teams used night-time radiative cooling in the SD ME 2018

255 competition. Evaporative cooling in Fig. 4 refers to the use of direct evaporative coolers and

256 indirect evaporative coolers. Evaporative cooling was first used in the SD Europe 2010

257 competition and this technology was more preferred in the competitions held in Europe as the

258 percentages of the teams used evaporative cooling were always not less than $15 \%$ in the SD

259 Europe competitions, while evaporative cooling was only used in the most recent competition

260 held in the US with a relatively low percentage (i.e. 9.1\% in the SD US 2017 competition). The

261 percentage of the teams using desiccant dehumidification was always less than $16 \%$ in the

262 previous SD competitions. The absorption/adsorption cooling was first used in the SD US 2007

263 competition and the application of this technology was quite limited probably due to its high

264 initial cost and high temperature (e.g. above $80{ }^{\circ} \mathrm{C}$ ) (Gomri, 2013; Shirazi et al., 2018) thermal

265 energy generally required which cannot be continuously provided by solar thermal systems.

266 It can be seen that the application of PCMs in the US competitions first increased to the

267 peak of $26.3 \%$ in 2011 and then decreased to less than $10 \%$ in recent competitions. The

268 percentage of the teams using PCMs in the SD Europe competitions remained at a relatively

269 high level of approximately 50\%. The highest percentage of $60.0 \%$ resulted in the SD China

2702013 competition however it should be noted that only 10 teams were reviewed for this

271 competition. It is also worthwhile to note that the above data included both active and passive

272 applications of PCMs such as using PCM as separate TES units and using PCMs in building

273 structure to enhance thermal mass. It can be observed that ERV/HRV is becoming more and

274 more popular in the SD competitions. In the SD US 2002 competition, the ERV/HRV was only 
used in $15.4 \%$ of the competition teams and it increased to $55.6 \%$ in the SD US 2005 competition. After that, more than $69 \%$ of the competition teams used this technology in the following competitions. The radiant heating was frequently used in the SD competitions. Compared to radiant heating, radiant cooling was much less frequently used in the SD competitions held in the SD US and China competitions while it was still a preferred option in the SD Europe and ME competitions.

From the above results, it can be seen that some technologies were preferred in some competitions. For instance, using solar thermal for space heating was not used in the SD ME 2018 competition due to its hot and humid weather conditions and was less frequently used in the SD US 2013 (Irvine, California) and 2015 (Irvine, California) competitions due to the relatively warm weather conditions in Irvine. The evaporative cooling was frequently used in the SD Europe 2010 (Madrid, Spain) and 2012 (Madrid, Spain) as the average maximum daily temperature and the average relative humidity of Madrid in July were $25.6{ }^{\circ} \mathrm{C}$ and $38 \%$, respectively (La Agencia Estatal de Meteorología, 2019). However, it seems that some technologies such as heat pumps, ERV/HRV, and radiant cooling, were not obviously 290 influenced by the location of the competition. used by the majority of the competition teams for space heating and space cooling probably

293 due to their reasonable prices and robustness to provide heating and cooling, easy to install, 294 and easy to control. The frequent use of air-to-air heat pumps may be due to the fact that their installation was easier than that of heat pumps using liquids as the heat transfer fluid. 
Solar thermal, night-time radiative cooling, and desiccant dehumidification were also

297 frequently used by the competition teams to showcase innovations and reduce the electricity consumption of the HVAC systems. The solar thermal space heating was the most frequently used renewable energy technology, as solar collectors are the mature technology and have been

of solar collectors to be used should be optimized in order to maximize the utilization of the available roof area and solar energy in SD houses. As solar energy is intermittent, the HVAC system needs to be grid-connected or integrated with thermal and/or electrical storage systems in order to continuously provide services.

\section{Overview of energy efficient HVAC solutions used in the Solar Decathlon competitions}

Fig. 5 shows the major HVAC technologies used in the previous SD competitions, in which the technologies that were not covered in this section were presented in grey boxes while those reviewed in this section were presented in boxes with different colors. Some of them such as

311 heat pumps, radiant panels, and ERV/HRV have been widely used by many competition teams

312 while some of them such as absorption cooling and adsorption cooling were only used in a few

313 houses. In this section, the HVAC technologies reviewed mainly included thermal energy

314 storage using PCMs, solar thermal energy for space heating, night-time radiative cooling,

315 desiccant dehumidification, evaporative cooling, and advanced control strategies. It is noted 316 that passive applications of PCMs, which integrated PCMs into building structures to increase 
317 building thermal mass only, thereby reducing heating and cooling demand of HVAC systems

318 and improving indoor thermal comfort (Lin et al., 2016), were not reviewed. The review of the

319 passive application of PCMs by a number of the competition teams participated in the early SD

320 US competitions and the SD Europe 2012 competition can be found in Rodríguez-Ubiñas et al.

321 (2011) and Rodriguez-Ubinas et al. (2014), respectively.

322

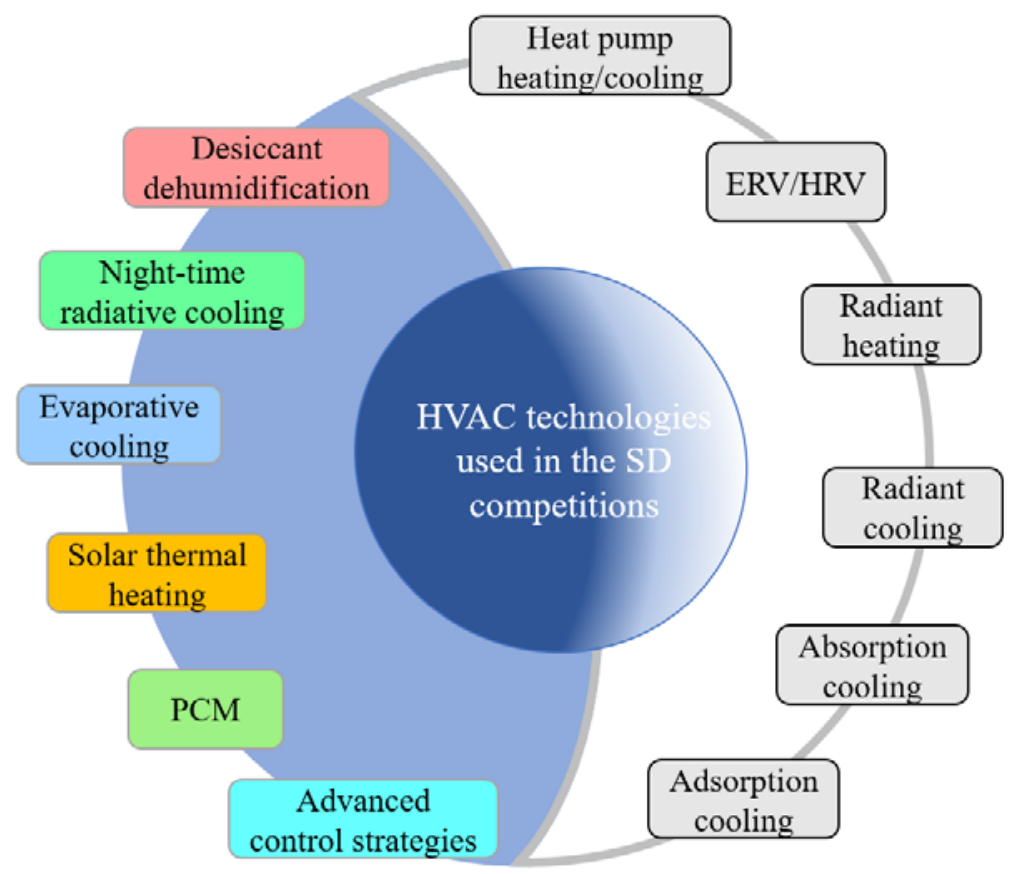

Fig. 5. Summary of main HVAC technologies used in the SD houses.

4.1 Thermal energy storage using PCMs

PCMs which have large energy storage densities and are available with different melting

temperatures have been widely considered as an energy efficient solution to enhance building energy efficiency (Ma et al., 2016; Rehman et al., 2019). A number of the competition teams that used PCM TES as stand-alone systems, and integrated PCM TES with building HVAC 
systems, as well as integrated PCMs into building structures but a heat transfer fluid was used to actively charge/discharge the PCM are reviewed hereafter. The details of the competition teams used PCM TES as stand-alone systems, and integrated PCM TES with building HVAC systems are summarized in Table 1. It is worthwhile to note that the PCM TES units used by a few teams were not included in Table 1 due to lack of the information.

It can be seen that PCMs were generally used as centralized TES units for storage of renewable and non-renewable thermal energy, such as solar thermal energy, ambient coolness/heat, night-time radiative cooling, evaporative cooling, and heating and cooling energy generated by heat pumps. A TES unit, for instance, which consisted of spheres filled with water and placed in a water tank, was used by Team Colorado (2007a, 2007b) in the US

3412007 competition. The TES unit enabled the ice thermal storage to shift the peak load of space

342 cooling in summer, and it was also served as a TES system to store solar thermal energy from

343 water-based photovoltaic-thermal (PVT) collectors and operated as the heat source of a water-

344 to-water heat pump in winter. In the SD US 2011 competition, a PCM TES tank with three coil

345 heat exchangers inside was developed by Team New York (2011). The PCM used was an 346 organic PCM of RT82 (Rubitherm GmbH, 2019). The PCM was charged by solar thermal 347 energy generated from evacuated tube solar collectors and the thermal energy was used to 348 power an adsorption chiller or drive radiant floor heating, and also used for domestic hot water.

349 The tank was designed by considering the volume change of the PCM during the phase change 350 process and the heat transfer performance between the PCM and the heat transfer fluid. A water- 
Fig. 6. PCM TES used in the HVAC system of Team UOW Desert Rose house for load shifting in the SDME 2018 competition.

In the SD Europe 2010 competition, Team Napevomo (Sánchez et al., 2010) installed four air-based PCM TES units under the floor for space cooling. The PCM was cooled by the ambient air during night-time and the indoor air temperature was regulated by circulating the air between the TES units and the indoor environment during daytime. An air-based PCM TES unit, as shown in Fig. 7a), was used in a solar-assisted HVAC system (Fig. 7b) in the SD China 
372 this system, the air-based PCM TES unit was used to store the heating and cooling energy

373 generated by the air-based PVT collectors via solar radiation and night-time radiative cooling,

374 respectively. The stored thermal energy was then used for space heating and cooling by

375 circulating the air between the PCM TES unit and the indoor environment, or for pre-heating

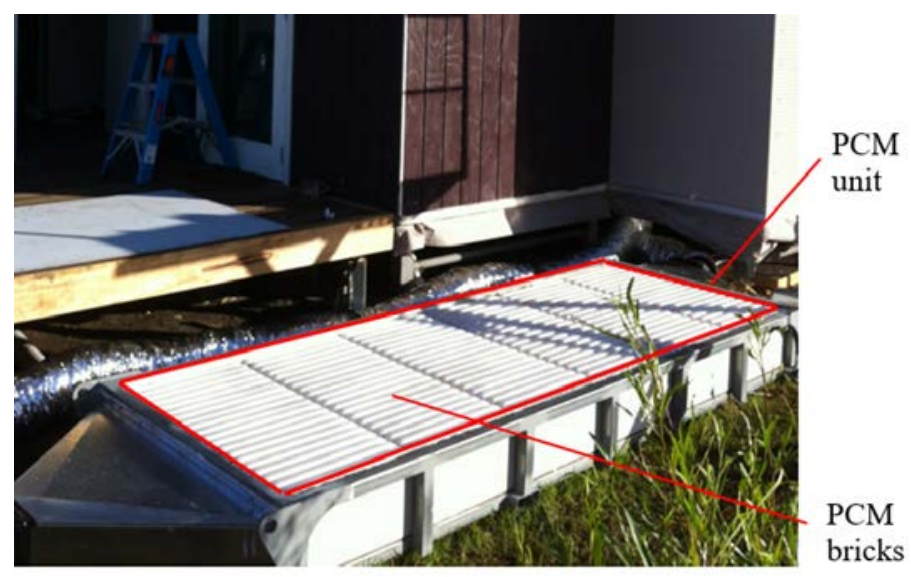

a) Air-based PCM TES system

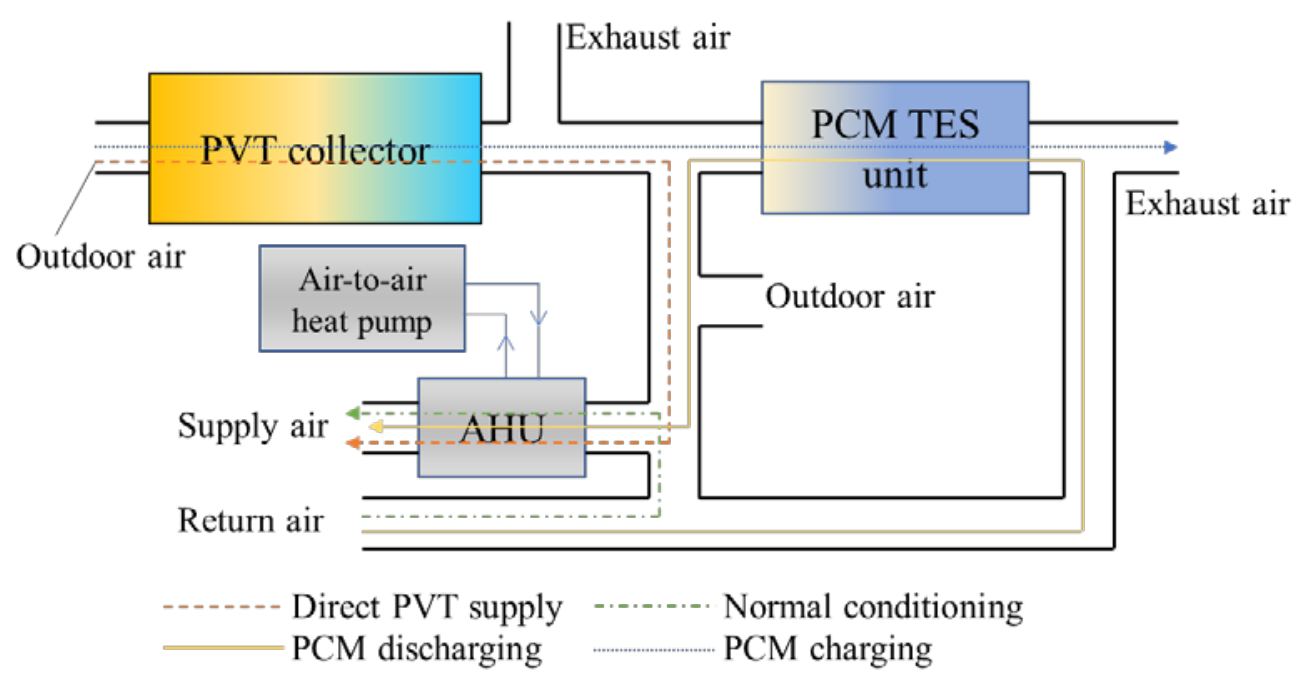


b) HVAC system with integrated PCM TES unit

382
Fig. 7. Illustration of the PCM TES and HVAC system developed by Team UOW for the SD China 2013 competition, modified from Fiorentini et al. (2015). 
402 the greenhouse double skin façade. During night-time, the thermal energy stored in the PCM 403 can be discharged passively, or can be discharged actively by circulating the air between the 404 PCM and the indoor environment via a fan. In summer, the night-time coolness was stored in 405 the PCM and it was released during the daytime for space cooling. A surface activated radiant 406 cooling system enhanced by PCMs was adopted by Team Darmstadt (2007) in the SD US 2007 407 competition. The micro-encapsulated PCM was embedded into plasterboards, and then 408 integrated onto the east and west walls, and ceilings. The PCM enhanced plasterboard on the 409 ceiling was coupled with capillary-tube mats for space cooling. It was charged using the chilled 410 water generated by a passive ceiling cooling system with water evaporation and sky radiative 411 cooling on the rooftop during the night-time. In the SD US 2011 competition, Team 412 Appalachian State (2011) developed a PCM-enhanced Trombe wall which consisted of 413 rotatable Trombe fins filled with oil-based PCM. The PCM was charged by the solar radiation 414 on the Trombe wall during daytime and the thermal energy could be passively released during 415 night-time for space heating. The Trombe fins could also be used to assist daylight control.

416 The above review showed that PCMs have been frequently used by the SD competition 417 teams to reduce energy consumption of the HVAC systems mainly through load shifting and 418 load reduction. The use of PCM TES could also facilitate the application of renewable heating 419 and/or cooling systems by solving the mismatch between the energy demand and solar thermal 420 energy generation, which could further reduce the energy consumption of HVAC systems or 421 even take air conditioning off the grid. However, the real performance of the SD houses due to 422 the use of PCMs was not reported. As PCMs are generally expensive in comparison with 
423 building construction materials, detailed performance optimization and cost benefit analysis 424 should be carried out during the decision-making process.

425 
426 Table 1. Summary of stand-alone PCM TES units and PCM TES units integrated with HVAC systems.

\begin{tabular}{|c|c|c|c|c|c|c|}
\hline \multirow[b]{2}{*}{ Team } & \multirow[b]{2}{*}{$\mathrm{HTF}$} & \multirow[b]{2}{*}{ Details of the TES units } & \multicolumn{3}{|c|}{ PCM used } & \multirow[b]{2}{*}{ Reference } \\
\hline & & & $\begin{array}{l}\text { Name/typ } \\
\text { e }\end{array}$ & $\begin{array}{l}\text { Melting } \\
\text { temp. }\left({ }^{\circ} \mathrm{C}\right)\end{array}$ & $\begin{array}{l}\text { Latent heat } \\
(\mathrm{kJ} / \mathrm{kg})\end{array}$ & \\
\hline RISD & Liquid & $\begin{array}{l}\text { PCM bricks were placed in a container under the } \\
\text { house and used as separate heat and cold sinks. }\end{array}$ & $\begin{array}{l}\text { Salt } \\
\text { hydrates }\end{array}$ & - & - & $\begin{array}{l}\text { Moon et al. (2005), U.S. } \\
\text { DOE (2005) }\end{array}$ \\
\hline Colorado & Liquid & $\begin{array}{l}\text { An ice TES system was integrated with a water-to- } \\
\text { water heat pump. }\end{array}$ & Ice & 0 & 334 & $\begin{array}{l}\text { Team Colorado (2007a, } \\
\text { 2007b) }\end{array}$ \\
\hline Germany & Air & $\begin{array}{l}\text { A TES was placed above the ceiling and charged } \\
\text { through night-time ventilation for space cooling. }\end{array}$ & $\begin{array}{l}\text { Delta- } \\
\text { COOL23 }\end{array}$ & $20-25$ & 185 & Team Germany (2009) \\
\hline Ohio State & Air & $\begin{array}{l}\text { PCM was filled in HDPE containers and placed in an } \\
\text { air-based TES unit; PCM was charged by wall- } \\
\text { integrated solar air heaters. }\end{array}$ & $\begin{array}{l}\text { PCM29P } \\
\text { (mainly } \\
\mathrm{CaCl}_{2} \\
\text { hexahydra } \\
\text { te) }\end{array}$ & 29 & - & $\begin{array}{l}\text { RGEES (2019), Team Ohio } \\
\text { State (2011) }\end{array}$ \\
\hline New York & Liquid & $\begin{array}{l}\text { PCM was filled in a TES tank with three coil heat } \\
\text { exchangers inside; PCM was charged by solar water } \\
\text { heaters, and used for space heating via radiant floor } \\
\text { and for space cooling via an adsorption chiller. }\end{array}$ & $\begin{array}{l}\text { RT82 } \\
\text { (Paraffin) }\end{array}$ & $77-82$ & 170 & $\begin{array}{l}\text { Team New York (2011), } \\
\text { Rubitherm GmbH (2019) }\end{array}$ \\
\hline $\begin{array}{l}\text { AZ State / } \\
\text { New } \\
\text { Mexico }\end{array}$ & Liquid & An ice TES unit was integrated with a chiller. & Ice & 0 & 334 & $\begin{array}{l}\text { Team AZ State / New } \\
\text { Mexico (2013) }\end{array}$ \\
\hline $\begin{array}{l}\text { Solar Cal } \\
\text { Poly }\end{array}$ & Air & $\begin{array}{l}\text { PCM was filled in the aluminum tubes and placed in } \\
\text { the air duct. }\end{array}$ & $\begin{array}{l}\text { BioPCM } \\
\text { (palm oil) }\end{array}$ & - & - & Team Solar Cal Poly (2015) \\
\hline Las Vegas & Air & $\begin{array}{l}\text { PCM was encapsulated into foil packets and installed } \\
\text { in a fresh air plenum; PCM was charged by ambient } \\
\text { heat or coolness. }\end{array}$ & $\begin{array}{l}\text { Eutectic } \\
\text { salt }\end{array}$ & 25.6 & - & Team Las Vegas (2017) \\
\hline
\end{tabular}


PCM was filled in the tubes and placed in a TES unit;

\begin{tabular}{|c|c|c|c|c|c|c|}
\hline Napevomo & Air & $\begin{array}{l}\text { PCM was charged by night-time ventilation and used } \\
\text { for space cooling. }\end{array}$ & - & - & - & Sánchez et al. (2010) \\
\hline $\begin{array}{l}\text { Bamboo } \\
\text { House }\end{array}$ & Air & $\begin{array}{l}\text { Four rectangular ventilation ducts with PCM bricks } \\
\text { were used to regulate indoor air temperature for both } \\
\text { space heating and cooling. }\end{array}$ & - & - & - & Sánchez et al. (2010) \\
\hline $\begin{array}{l}\text { URCOMA } \\
\text { NTE }\end{array}$ & Liquid & $\begin{array}{l}\text { PCM was used to emulate thermal inertia of the earth } \\
\text { for a geothermal heat pump. }\end{array}$ & - & - & - & Sánchez et al. (2010) \\
\hline $\begin{array}{l}\text { Rhône- } \\
\text { Alpes }\end{array}$ & Liquid & $\begin{array}{l}\text { PCMs with different phase change temperatures were } \\
\text { filled in a water tank and charged by PVT collectors } \\
\text { via solar thermal energy and night-time radiative } \\
\text { cooling, respectively, or by a heat pump, and used for } \\
\text { indoor radiant heating and cooling. }\end{array}$ & - & $35 / 10$ & - & Team Rhône-Alpes (2012) \\
\hline $\begin{array}{l}\text { RWTH } \\
\text { Aachen } \\
\text { University }\end{array}$ & Liquid & $\begin{array}{l}\text { PCM emulsion was used as the working fluid for } \\
\text { space cooling, and was cooled by night-time radiative } \\
\text { cooling and water evaporation. }\end{array}$ & $\begin{array}{l}\text { PCM } \\
\text { emulsion } \\
\text { (RT20 } \\
\text { based) }\end{array}$ & $16-22$ & 40 & $\begin{array}{l}\text { Team RWTH Aachen } \\
\text { University (2012), Hanu et } \\
\text { al. (2012) }\end{array}$ \\
\hline $\begin{array}{l}\text { CEU Team } \\
\text { Valencia }\end{array}$ & Liquid & $\begin{array}{l}\text { Two PCM tanks were integrated with a heat pump } \\
\text { for space cooling; One was used as the heat sink } \\
\text { while the other was used as cold storage. }\end{array}$ & - & - & - & $\begin{array}{l}\text { CEU Team Valencia (2012), } \\
\text { Real et al. (2014) }\end{array}$ \\
\hline $\begin{array}{l}\text { Aquitaine } \\
\text { Bordeaux } \\
\text { Campus }\end{array}$ & Air & $\begin{array}{l}\text { Three PCM heat exchangers were used for space } \\
\text { cooling by using the coolness generated via night- } \\
\text { time ventilation. }\end{array}$ & Paraffin & 21 & - & $\begin{array}{l}\text { Team Aquitaine Bordeaux } \\
\text { Campus (2012) }\end{array}$ \\
\hline $\begin{array}{l}\text { équipe } \\
\text { VIA-UJI }\end{array}$ & Air & $\begin{array}{l}\text { PCM was charged by the heated air from a } \\
\text { greenhouse and discharged during night-time for }\end{array}$ & S25 & 25 & 180 & Team équipe VIA-UJI (2014) \\
\hline
\end{tabular}


PCM was charged by the heated air from the solar air

\begin{tabular}{|c|c|c|c|c|c|c|}
\hline FENIX & Air & $\begin{array}{l}\text { heater and discharged during night-time for space } \\
\text { heating. }\end{array}$ & - & $25-28$ & - & Team FENIX (2014) \\
\hline Réciprocité & Air & $\begin{array}{l}\text { The system used was similar to that used by Team } \\
\text { FENIX (2014). }\end{array}$ & - & 46 & - & Team Réciprocité (2014) \\
\hline UOW & Air & $\begin{array}{l}\text { PCM was filled in the plastic containers and placed } \\
\text { in a TES unit; PCM was heated and cooled via solar } \\
\text { thermal energy and night-time radiative cooling, as } \\
\text { well as a heat pump. }\end{array}$ & $\begin{array}{l}\text { PlusICE } \\
\text { S21 }\end{array}$ & 22 & 170 & $\begin{array}{l}\text { Fiorentini et al. (2015), PCM } \\
\text { products Ltd. (2019) }\end{array}$ \\
\hline UOW & Liquid & $\begin{array}{l}\text { A TES unit with a number of HDPE tubes filled with } \\
\text { PCM was used to store cooling energy for load } \\
\text { shifting and demand side management. }\end{array}$ & $\begin{array}{l}\text { TubeICE } \\
\text { S10 }\end{array}$ & 10 & 155 & $\begin{array}{l}\text { Team UOW (2018), PCM } \\
\text { products Ltd. (2019) }\end{array}$ \\
\hline ORA & Air & $\begin{array}{l}\text { A PCM TES unit was charged by night-time } \\
\text { ventilation and used for space cooling. }\end{array}$ & $\begin{array}{l}\text { PlusICE } \\
\text { S32 }\end{array}$ & 32 & 200 & $\begin{array}{l}\text { Team ORA (2018), PCM } \\
\text { products Ltd. (2019) }\end{array}$ \\
\hline
\end{tabular}


428 Table 2. Summary of the PCMs actively used in building structure of the SD houses.

\begin{tabular}{|c|c|c|c|c|c|c|}
\hline \multirow[b]{2}{*}{ Team } & \multirow[b]{2}{*}{ HTF } & \multirow[b]{2}{*}{ Details of the TES systems } & \multicolumn{3}{|c|}{ PCM used } & \multirow[b]{2}{*}{ Reference } \\
\hline & & & Name/type & $\begin{array}{l}\text { Melting } \\
\text { temp. }\left({ }^{\circ} \mathrm{C}\right)\end{array}$ & $\begin{array}{l}\text { Latent heat } \\
(\mathrm{kJ} / \mathrm{kg})\end{array}$ & \\
\hline Madrid & Air & $\begin{array}{l}\text { PCM was placed under the floor and used for intake air } \\
\text { preheating and precooling; PCM was charged through } \\
\text { greenhouse double-skin façade. }\end{array}$ & - & $22-24$ & - & $\begin{array}{l}\text { Moon et al. (2005), } \\
\text { Hernández-Martínez } \\
\text { (2011) }\end{array}$ \\
\hline Canadian & Air & $\begin{array}{l}\text { PCM-soaked bricks were placed beneath the floor; PCM } \\
\text { was charged by PVT collectors and used for space } \\
\text { heating. }\end{array}$ & $\begin{array}{l}\text { Organic } \\
\text { mixture }\end{array}$ & - & - & $\begin{array}{l}\text { Moon et al. (2005), } \\
\text { U.S. DOE (2005) }\end{array}$ \\
\hline Darmstadt & Liquid & $\begin{array}{l}\text { PCM was integrated with a chilled ceiling and charged } \\
\text { by the water which was cooled via evaporative cooling. }\end{array}$ & $\begin{array}{l}\text { Micronal } \\
\text { plaster board }\end{array}$ & - & - & $\begin{array}{l}\text { Team Darmstadt } \\
\text { (2007) }\end{array}$ \\
\hline $\begin{array}{l}\text { Appalachi } \\
\text { an State }\end{array}$ & Air & $\begin{array}{l}\text { PCM was integrated with rotatable fins of a Trombe } \\
\text { wall and was charged by solar radiation for space } \\
\text { heating. }\end{array}$ & $\begin{array}{l}\text { BioPCM - } \\
27 \mathrm{M}\end{array}$ & 27 & $165-200$ & $\begin{array}{l}\text { Team Appalachian } \\
\text { State (2011) }\end{array}$ \\
\hline home $^{+}$ & $\begin{array}{l}\text { Liquid/ } \\
\text { Air }\end{array}$ & $\begin{array}{l}\text { PCM was integrated with a chilled ceiling and charged } \\
\text { by a PVT collector via night-time radiative cooling, or a } \\
\text { heat pump, or evaporative cooling. }\end{array}$ & - & $21-23$ & - & Sánchez et al. (2010) \\
\hline $\begin{array}{l}\text { IKAROS } \\
\text { Bavaria }\end{array}$ & Liquid & $\begin{array}{l}\text { PCM was integrated with a radiant ceiling for both space } \\
\text { heating and cooling, which was integrated with a heat } \\
\text { pump. }\end{array}$ & - & - & - & Sánchez et al. (2010) \\
\hline ECOLAR & Liquid & $\begin{array}{l}\text { PCM was integrated with a chilled ceiling and charged } \\
\text { by a PVT collector via night-time radiative cooling or a } \\
\text { heat pump. }\end{array}$ & - & - & - & $\begin{array}{l}\text { Team ECOLAR } \\
\text { (2012) }\end{array}$ \\
\hline $\begin{array}{l}\text { Chiba } \\
\text { University }\end{array}$ & Air & $\begin{array}{l}\text { PCM was filled in the containers and placed under the } \\
\text { floor, which was integrated with a raised floor air } \\
\text { conditioning system for both space heating and cooling. }\end{array}$ & Paraffin & 21 & 100 & $\begin{array}{l}\text { Team Chiba } \\
\text { University (2014) }\end{array}$ \\
\hline
\end{tabular}


PCM was integrated with a chilled ceiling, and charged

Rooftop Liquid by a heat pump or night-time natural ventilation or

evaporative cooling via a constructed wet-land.

Virginia PCM was mounted on the ceiling for demand-side

Tech Air management. It was charged by the HVAC system and used for space cooling at non-solar production period.

Team Virginia Tech

(2018) 
A number of the SD houses used solar thermal energy for space heating. The types of solar collectors and delivering methods used as well as the number of the teams which used different solar thermal technologies for space heating are summarized in Fig. 8. Solar collectors could be generally categorized into water-based collectors and air-based collectors dependent on the heat transfer fluid used. The water-based solar collectors used for space heating could be further categorized into evacuated tube solar collectors, flat-plate solar collectors, photovoltaicthermal (PVT) collectors, and concentrating solar collectors. The delivering methods were required when water-based solar collectors are used, which could be categorized into three types including radiant panels, forcing air, and hybrid method which used both radiant panels

440 and forcing air. The air-based solar collectors could be categorized into solar air heaters and 441 air-based PVT collectors, and thermal energy collected could be directly delivered into the 442 indoor space via air flow. It can be clearly seen that water-based collectors were used by many 443 competition teams for space heating. Among different water-based collectors, evacuated tube 444 collectors were used by 47 teams, which was the most popular type of solar collectors. The 445 flat-plate solar collectors and PVT collectors were also used by a number of the competition 446 teams, while concentrating solar collectors were only used by 3 teams. The air-based solar 447 collector was used by only 7 teams. The number of the teams used radiant panels was almost 448 doubled than that used forced air to deliver thermal energy generated by water-based collectors, 449 and a few teams used both delivering methods. 'Unclear' in Fig. 8 indicated that the type of solar collectors and the delivering methods were not clearly stated. 
452

453

454

455

456

457

458

459

460

461

462

463

464

465

466

467
Solar air heater (2)

Photovoltaic-thermal collector (5)

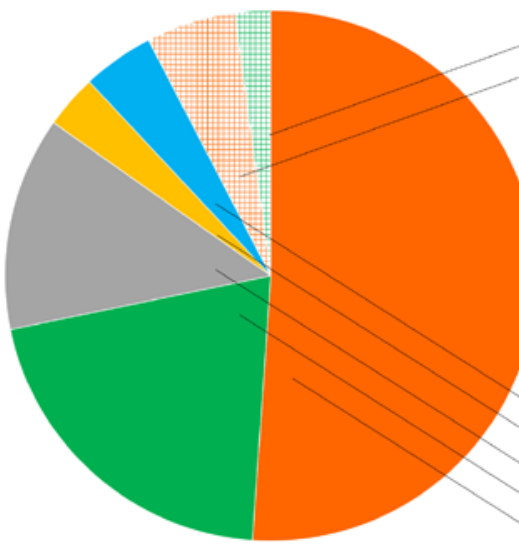

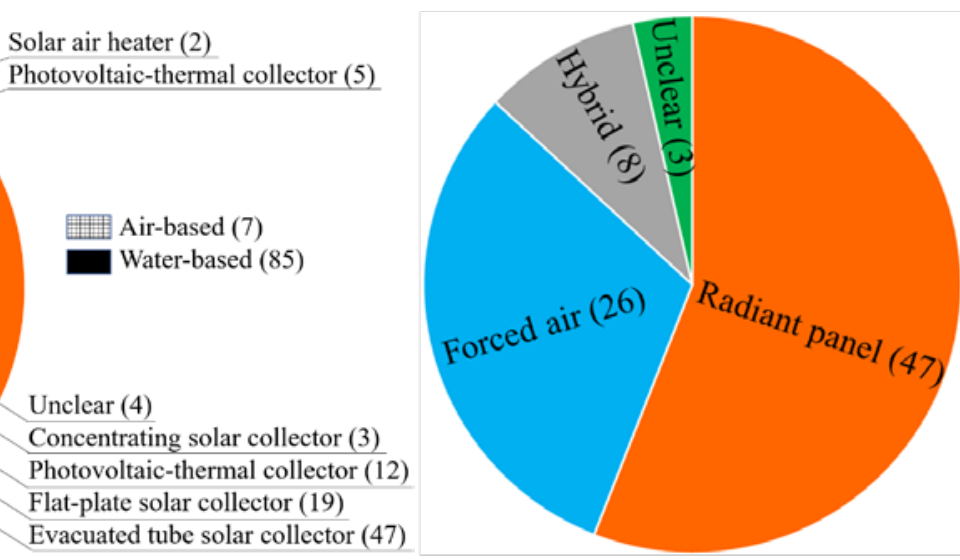

Photovoltaic-thermal collector (12)

Flat-plate solar collector (19)

Evacuated tube solar collector (47)
a) Types of solar collectors
b) Delivering methods for water-based collectors

Fig. 8. Summary of solar collectors and delivering methods used in solar thermal space heating systems of the SD houses.

Some solar thermal space heating technologies used in the SD houses are briefly introduced herein. In the SD US 2007 competition, Team Texas (2007) developed a solar thermal space heating system by using evacuated tube solar collectors and a radiant floor heating system to generate hot water and deliver thermal energy to the indoor space, respectively. A similar design was also adopted by a number of the competition teams. Team Cincinnati (2007) also utilized the evacuated tube solar collectors for space heating while the thermal energy was delivered by using both a radiant floor heating system and a water-to-air heat exchanger in the SD US 2007 competition. Team Ontario/BC (2009) developed a solar thermal space heating system by integrating a heat pump with evacuated tube solar collectors in the SD US 2009 competition. The hot water generated by the solar collectors can be directly used for space heating via an air handling unit or used as the heat source of a water-to-water 
heat pump to enhance its performance for water heating. Using solar thermal energy as the heat source of heat pumps was also adopted by 10 teams and 11 teams from the SD competitions held in the US and Europe, respectively. A solar thermal space heating system assisted by solar

471 air heaters, an air-based PCM TES unit, and flat-plate solar water heaters was developed by 472 Team Ohio State (2011) in the SD US 2011 competition. The air-based solar thermal collectors 473 were installed on the south-facing wall of the house and used to provide hot air for space 474 heating. The flat-plate solar water heaters were used to generate hot water for both domestic 475 hot water and space heating. When space heating was required, the thermal energy generated by the flat-plate solar water heater was used to provide hot water for a hydronic heating coil in an air handling unit. The hot air generated by the solar air heaters first passed through the TES unit for PCM charging and then supplied to the air handling unit as pre-heated air for space heating. The thermal energy stored in the PCM can be used for space heating when the solar radiation was low.

The above review showed that solar thermal space heating was mainly used for pre-heating and/or as a supplementary heating system of HVAC systems. Water-based solar thermal space 483 heating was more frequently used in the previous SD competitions, as compared to air-based 484 solar thermal space heating. Radiant panels were the most frequently used delivering method 485 for solar thermal space heating.

4.3 Night-time radiative cooling

Night-time radiative cooling utilizes heat loss through long-wave radiation to the sky to 488 provide cooling (Eicker and Dalibard, 2011). This technology has attracted increasing interest 
as it requires negligible energy consumption when comparing to conventional vapor compression systems. The details of the major night-time radiative cooling technologies used in the SD houses are summarized in Table 3.

492

The night-time radiative cooling technologies can be categorized into water-based technologies and air-based technologies according to the heat transfer fluid used. Team RWTH Aachen University (2012) adopted a water-based PVT system for night-time radiative cooling 495 in the SD Europe 2012 competition. Rainwater was collected and spread onto the PV panel during the night-time to cool the water via the heat loss to the sky. The chilled rainwater was then used to cool a PCM emulsion in a radiant ceiling for space cooling. Team Odooproject (2012) also used a similar water-based night-time radiative cooling PV panel in the SD Europe 2012 competition, while the chilled water was directly used for space cooling. Team UC Davis used sprinklers to spray water onto the roof surface to achieve night-time radiative cooling in the SD US 2015 competition (Alemi and Loge, 2017; Team UC Davis, 2015).

503 a heat exchanger to the back of a surface that was chilled by the heat loss to the sky. In the SD

504 Europe 2010 competition, Team home ${ }^{+}$developed a water-based night-time radiative PVT 505 system (see Fig. 9) which consisted of PV cells covered and supported by glass and water tubes 506 with absorber plates attached to the bottom of the lower glass (Eicker and Dalibard, 2011; 507 Sánchez et al., 2010). The night-time radiative PVT was used to provide chilled water for a 508 PCM ceiling, a radiant floor, and a heat sink tank. Similar devices were also used by Team 
510 based solar collectors were also used for night-time radiative cooling by Team DTU in the SD

511 Europe 2014 competition (Gennari and Péan, 2014; Team DTU, 2014), Team Israel (2013) in

512 the SD China 2013 competition, and Team North Carolina (2013) in the SD US 2013

513 competition.

514

515

516

517

518

519

520

521

522

523

524

525

526

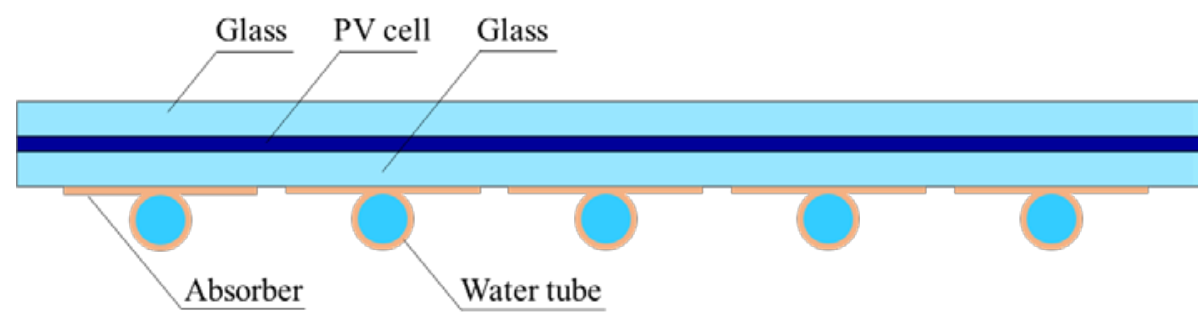

Fig. 9. Night-time radiative PVT system used by Team home ${ }^{+}$, modified from Eicker and Dalibard (2011).

An air-based night-time radiative cooling system was used by Team UOW in the SD China 2013 competition (Fiorentini et al., 2015; Fiorentini et al., 2017). Air-based PVT collectors were used in the HVAC system which integrated with a PCM TES unit, as presented in Fig. 7, to generate electricity during daytime and cooling energy via night-time radiative cooling during night time. The cooled air could be used for space cooling directly or used to charge the air-based PCM TES unit.

Based on the systems reviewed above, it can be seen that the cooling provided by the nighttime radiative cooling effect was mainly delivered via radiant panels. Only two teams used airbased night-time radiative cooling. Night-time radiative cooling alone may not be able to maintain indoor thermal comfort. It can be used to assist in improving the performance of the HVAC systems. The night-time radiative cooling could provide nearly free cooling during night 
529 with minimized energy consumption. This technology has attracted increasing attention in 530 recent years (Zeyghami et al., 2018; Zhao et al., 2019), and the emerging day-time radiative 531 cooling may provide alternative solutions for the SD houses (Raman et al., 2014; Goldstein et 532 al., 2017). 
533 Table 3. Summary of night-time radiative cooling technologies used in the SD competitions.

\begin{tabular}{|c|c|c|c|c|}
\hline Team & $\begin{array}{l}\text { Radiative } \\
\text { surface }\end{array}$ & HTF & Details & Reference \\
\hline Crowder & $\begin{array}{l}\text { PVT } \\
\text { collector }\end{array}$ & Liquid & PVT collectors were used to chill water for air conditioning. & Moon et al. 2005 \\
\hline Colorado & $\begin{array}{l}\text { PVT } \\
\text { collector }\end{array}$ & Liquid & $\begin{array}{l}\text { HTF was chilled by the PVT collector and stored in a tank which was used as } \\
\text { the heat sink of a water-to-water heat pump. }\end{array}$ & $\begin{array}{l}\text { Team Colorado (2007a, } \\
\text { 2008b) }\end{array}$ \\
\hline Darmstadt & Roof surface & Liquid & $\begin{array}{l}\text { Overnight, water was sprayed onto the roof of the house and chilled by a } \\
\text { passive cooling system; The chilled water was used for space cooling via } \\
\text { radiant panels. }\end{array}$ & $\begin{array}{l}\text { Team Darmstadt (2007), } \\
\text { Eicker and Dalibard (2011) }\end{array}$ \\
\hline $\begin{array}{l}\text { North } \\
\text { Carolina }\end{array}$ & $\begin{array}{l}\text { Rooftop heat } \\
\text { exchanger }\end{array}$ & Liquid & $\begin{array}{l}\text { HTF was pumped into flat-plate heat exchangers on the rooftop, and used for } \\
\text { space cooling via radiant walls and ceiling. }\end{array}$ & Team North Carolina (2013) \\
\hline UC Davis & Roof surface & Liquid & $\begin{array}{l}\text { HTF was sprayed onto the roof surface by lawn sprinklers to achieve night- } \\
\text { time radiative cooling, and used for space cooling via radiant floor. }\end{array}$ & $\begin{array}{l}\text { Alemi and Loge (2017), Team } \\
\text { UC Davis (2015) }\end{array}$ \\
\hline home $^{+}$ & $\begin{array}{l}\text { PVT } \\
\text { collector }\end{array}$ & Liquid & $\begin{array}{l}\text { Water was chilled by the night-time radiative cooling system on the roof, and } \\
\text { supplied to a PCM ceiling, radiant floor and a heat sink tank. }\end{array}$ & $\begin{array}{l}\text { Eicker and Dalibard (2011), } \\
\text { Sánchez et al. (2010) }\end{array}$ \\
\hline $\begin{array}{l}\text { Rhône- } \\
\text { Alpes }\end{array}$ & $\begin{array}{l}\text { PVT } \\
\text { collector }\end{array}$ & Liquid & $\begin{array}{l}\text { Water was chilled by a heat exchanger beneath the PV panel, and used as the } \\
\text { heat sink of a water-to-water heat pump, or stored in a thermal storage tank. }\end{array}$ & Team Rhône-Alpes (2012) \\
\hline ECOLAR & $\begin{array}{l}\text { PVT } \\
\text { collector }\end{array}$ & Liquid & $\begin{array}{l}\text { HTF was chilled by a flat plastic absorber beneath the PV panel, and used for } \\
\text { space cooling via radiant ceiling with embedded PCM and two water-to-air } \\
\text { heat exchangers. }\end{array}$ & Team ECOLAR (2012) \\
\hline $\begin{array}{l}\text { RWTH } \\
\text { Aachen } \\
\text { University }\end{array}$ & PV panel & Liquid & $\begin{array}{l}\text { Water was sprayed onto the PV panel by a sprinkler system and chilled by } \\
\text { night-time radiative cooling, and used to cool the PCM emulsion in the radiant } \\
\text { ceiling. }\end{array}$ & $\begin{array}{l}\text { Team RWTH Aachen } \\
\text { University (2012) }\end{array}$ \\
\hline Odooproject & PV panel & Liquid & $\begin{array}{l}\text { Water was sprayed onto the PV panel by sprinkler heads and chilled by night- } \\
\text { time radiative cooling, and used for space cooling via the radiant ceiling. }\end{array}$ & Team Odooproject (2012) \\
\hline (e)со & - & Air & A tank filled with gravel was opened during night-time to achieve radiative & (e)co Team (2012) \\
\hline
\end{tabular}


cooling, which served as a sensible TES unit and was discharged during daytime for space cooling.

\begin{tabular}{|c|c|c|c|c|}
\hline Tongji & - & Liquid & $\begin{array}{l}\text { Water was chilled by night-time radiative cooling, and was used for space } \\
\text { cooling directly or used as the heat sink of a heat pump for space cooling. }\end{array}$ & Team Tongji (2012) \\
\hline DTU & $\begin{array}{l}\text { Unglazed } \\
\text { solar } \\
\text { collector }\end{array}$ & Liquid & $\begin{array}{l}\text { Water was chilled by night-time radiative cooling and used for space cooling } \\
\text { via radiant floor }\end{array}$ & $\begin{array}{l}\text { Gennari and Péan (2014), } \\
\text { Team DTU (2014) }\end{array}$ \\
\hline UOW & $\begin{array}{l}\text { PVT } \\
\text { collector }\end{array}$ & Air & $\begin{array}{l}\text { Air was cooled by air-based PVT collectors with air channels beneath PV } \\
\text { panels, and directly used for space cooling or to charge an air-based PCM TES } \\
\text { unit. }\end{array}$ & $\begin{array}{l}\text { Fiorentini et al. (2017), } \\
\text { Fiorentini et al. (2015) }\end{array}$ \\
\hline BaityKool & $\begin{array}{l}\text { Thermal } \\
\text { radiator }\end{array}$ & Liquid & $\begin{array}{l}\text { A thermal radiator was installed on the roof of the house and used to chill the } \\
\text { water during night-time; The chilled water was used for space cooling via } \\
\text { radiant panels. }\end{array}$ & Team BaityKool (2018) \\
\hline VIRTUe & $\begin{array}{l}\text { PVT } \\
\text { collector }\end{array}$ & Liquid & $\begin{array}{l}\text { Water was cooled by water-based PVT collectors and stored in a chilled water } \\
\text { thank; The chilled water was used for space cooling via radiant panels. }\end{array}$ & Team VIRTUe (2018) \\
\hline
\end{tabular}




\subsection{Desiccant dehumidification}

536

Desiccant dehumidification utilizes hygroscopic materials to absorb moisture from the air.

537 The materials usually need to be regenerated with thermal energy to reject the moisture into ambient, and the hygroscopic material was then reused for dehumidification. This regeneration process could be driven by low-grade thermal energy such as solar thermal energy, which opens up opportunities for the SD houses (Giampieri et al., 2018; Ren et al., 2019b). The major desiccant dehumidification systems and devices used in the SD houses are summarized in Table 4. Both liquid desiccant and solid desiccant (i.e. desiccant wheel and DESICA) systems have been used.

Liquid desiccant dehumidification generally consists of a dehumidifier, a regenerator, and

545 heating and cooling systems. The dehumidifier is an air-to-liquid contactor in which air is

546 dehumidified by the liquid desiccant via an absorption process. The regenerator operates in the opposite way and the water is desorbed from the liquid desiccant using scavenging air, in which

548 the liquid desiccant was concentrated and reused for the dehumidification. The heating and

549 cooling systems were respectively used to heat the liquid desiccant and to cool the liquid

550 desiccant in order to facilitate the regeneration and dehumidification processes. Two liquid

551 desiccant waterfall systems were developed by Team Maryland in the SD US 2007 and SD US

5522011 competitions (Team Maryland, 2007a, 2007b; Team Maryland, 2011), using $\mathrm{CaCl}_{2}$ and

$553 \mathrm{LiCl}$ water solutions as the desiccants, respectively. The indoor units (i.e. dehumidifiers) of

554 both liquid desiccant systems were designed as the waterfall for aesthetic purpose. A schematic

555 of the dehumidification system used in the SD US 2011 competition is presented in Fig. 10 
556 (Team Maryland, 2011). The indoor air was dehumidified by the waterfall (i.e. dehumidifier)

557 via directly contacting with the concentrated liquid desiccant. The diluted liquid desiccant was

558 then pumped to a heat exchanger and heated by glycol from solar collectors, after which the

559 liquid desiccant was re-concentrated by the regenerator. A liquid desiccant waterfall system

560 was also used by Team Florida (2011) in the SD US 2011 competition.

561

562

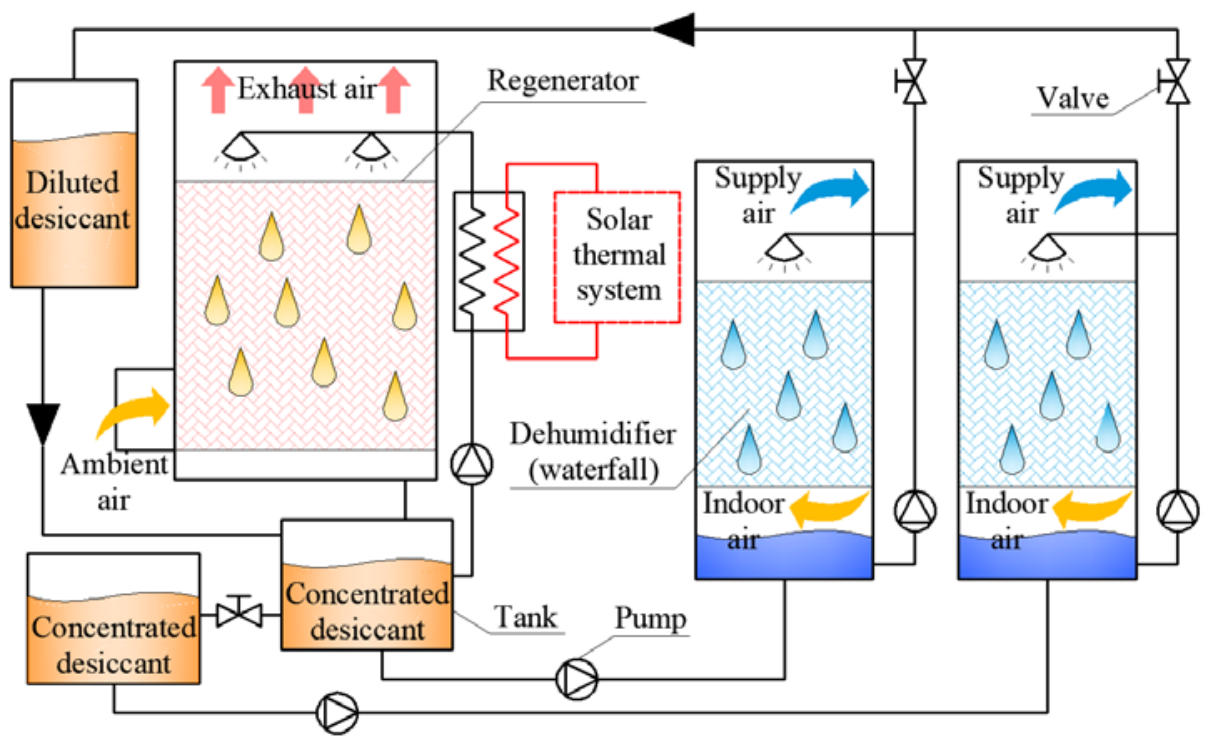

563 Fig. 10. Schematic of the liquid desiccant waterfall system developed by Team Maryland in the US 2011 competition, modified from Team Maryland (2011). to the dehumidifier through ducting and re-supplied to the indoor space after it was 
using $\mathrm{CaCl}_{2}$ solution was developed by Team Iowa State (2009) in the SD US 2009 competition.

573 The dehumidifier was integrated into the air distribution system of the HVAC system, and a

574 liquid-to-liquid heat exchanger was used to exchange the heat between the liquid desiccant at

575 the outlets of the dehumidifier and regenerator. A liquid desiccant dehumidification system

576 including an indoor unit, a roof unit, and a solution tank was developed by Team Stevens

577 (2013a, 2013b) in the SD US 2013 competition. The indoor unit operated as a dehumidifier

and the roof unit worked as the regenerator which used the greenhouse effect as the heat source

579

to evaporate water from the liquid desiccant.

580

A desiccant wheel with a size of $0.3 \mathrm{~m} \times 0.1 \mathrm{~m}$ was used by Team Ohio State in the SD

US 2011 competition (O’Kelly et al., 2015; Team Ohio State, 2011) to deal with the latent load

with the assistance of an ERV and a hydronic cooling coil. Air-based solar thermal collectors

583

were used to provide thermal energy for the desiccant wheel regeneration. A desiccant wheel regenerated by solar thermal energy was also used by Team Réciprocité (2014) in the SD

585 Europe 2014 competition while evacuated tube solar collectors and a water-to-air heat

586 exchanger were used to provide hot air for the regeneration process. A commercial product

587 which integrated a desiccant wheel with an air-to-air heat pump was used by Team Alberta

588 (2013) in the US 2013 competition and Team TEC (2014) in the SD Europe 2014 competition.

589 The evaporator of the heat pump was used to cool the air before it was dehumidified by the

590 desiccant wheel, and the heated air from the condenser of the heat pump was used to regenerate

591 the desiccant wheel. The supply air can be cooled and dehumidified simultaneously while extra

592 electricity was required to power the heat pump. A commercial product, DESICA, was used by 
593 Team Tongji (2012) and Team UOW (2018) for desiccant dehumidification in the SD Europe

5942012 and SD ME 2018 competitions, respectively. The DESICA was essentially an air-to-air

595 heat pump which used desiccant-coated heat exchangers as the evaporator and condenser.

596 During the dehumidification process, the evaporator and condenser were continuously

597 swapped in order to regenerate the desiccants.

598 Based on the systems reviewed above, it can be concluded that desiccant dehumidification

599 was mainly used as supplementary dehumidification devices to HVAC systems for better

600 humidity control, and the dehumidification systems were mainly driven by solar thermal energy.

601 The liquid desiccant systems used in the SD houses were mainly designed and developed by

602 the team members as there are limited commercial products available. However, liquid

603 desiccant cooling is now close to being viable and its economic proposition is now better than

604 before due to the development of corrosion resistant materials (e.g. plastic) and improvement

605 in heat and mass transfer efficiency (Giampieri et al., 2018; Fu and Liu, 2017).

606 
607 Table 4. Summary of desiccant dehumidification technologies used in the previous SD competitions.

\begin{tabular}{|c|c|c|c|c|}
\hline Team & Types & $\begin{array}{l}\text { Desiccant } \\
\text { materials }\end{array}$ & Details & Reference \\
\hline Maryland & $\mathrm{LD}$ & $\mathrm{CaCl}_{2}$ & $\begin{array}{l}\text { A liquid desiccant waterfall was used as the dehumidifier; The liquid desiccant } \\
\text { was regenerated using solar hot water. }\end{array}$ & $\begin{array}{l}\text { Team Maryland (2007a, } \\
\text { 2007b) }\end{array}$ \\
\hline Iowa State & LD & $\mathrm{CaCl}_{2}$ & $\begin{array}{l}\text { A flat-plate dehumidifier was integrated into the ducting of the HVAC system; } \\
\text { The liquid desiccant was regenerated using an internally-heated regenerator } \\
\text { with solar hot water. }\end{array}$ & Team Iowa State (2009) \\
\hline Minnesota & LD & $\begin{array}{l}\mathrm{LiCl} \text { and } \\
\mathrm{CaCl}_{2}\end{array}$ & $\begin{array}{l}\text { Pack-bed dehumidifier/regenerator with random packing was used; The liquid } \\
\text { desiccant was heated by a heat exchanger using solar thermal energy, before } \\
\text { supplied to the regenerator. }\end{array}$ & Team Minnesota (2009) \\
\hline $\begin{array}{l}\text { Team } \\
\text { Florida }\end{array}$ & LD & $\mathrm{CaCl}_{2}$ & $\begin{array}{l}\text { A liquid desiccant waterfall was used as the dehumidifier; The liquid desiccant } \\
\text { was regenerated in a solution tank. }\end{array}$ & Team Florida (2011) \\
\hline Maryland & LD & $\mathrm{LiCl}$ & $\begin{array}{l}\text { Two liquid desiccant waterfalls were used as the dehumidifiers; The liquid } \\
\text { desiccant was regenerated using solar hot water. }\end{array}$ & Team Maryland (2011) \\
\hline Stevens & LD & $\mathrm{CaCl}_{2}$ & $\begin{array}{l}\text { A packed-bed column with trays filled with } 76 \mathrm{~mm} \text { Heilex Rings was used as } \\
\text { the dehumidifier; The liquid desiccant was regenerated by an outside unit on the } \\
\text { roof via the greenhouse effect. }\end{array}$ & $\begin{array}{l}\text { Team Stevens (2013a, } \\
\text { 2013b) }\end{array}$ \\
\hline $\begin{array}{l}\text { Team } \\
\text { Alabama }\end{array}$ & LD & $\mathrm{CaCl}_{2}$ & Pack-bed dehumidifier/regenerator with structured packing was used. & Team Alabama (2017) \\
\hline $\begin{array}{l}\text { RWTH } \\
\text { Aachen } \\
\text { University }\end{array}$ & LD & $\mathrm{LiCl}$ & $\begin{array}{l}\text { The liquid desiccant was regenerated using solar thermal energy from solar } \\
\text { water heaters. }\end{array}$ & $\begin{array}{l}\text { Team RWTH Aachen } \\
\text { University (2012) }\end{array}$ \\
\hline Ohio State & DW & - & $\begin{array}{l}\text { A desiccant wheel was used to dehumidify the supply air and it was regenerated } \\
\text { using the heated air from solar air heaters. }\end{array}$ & $\begin{array}{l}\text { O’Kelly et al. (2015), Team } \\
\text { Ohio State (2011) }\end{array}$ \\
\hline Alberta* & DW & - & $\begin{array}{l}\text { A commercial product, which was an integration of a desiccant wheel and an } \\
\text { air-to-air heat pump, was used; The condensing heat of the heat pump was used }\end{array}$ & Team Alberta (2013) \\
\hline
\end{tabular}


for desiccant wheel regeneration and the evaporator was used for air cooling.

\begin{tabular}{|c|c|c|c|c|}
\hline Réciprocité & DW & - & $\begin{array}{l}\text { A desiccant wheel was used to dehumidify the supply air; The regeneration air } \\
\text { was heated by a water-to-air heat exchanger mainly using solar hot water. }\end{array}$ & Team Réciprocité (2014) \\
\hline TEC & DW & - & The same product as that used by Team Alberta (US 2013). & Team TEC (2014) \\
\hline Tongji & DESICA & - & $\begin{array}{l}\text { DESICA which was an air-to-air heat pump with desiccant material coated on } \\
\text { both the evaporator and condenser was used to dehumidify the fresh air. }\end{array}$ & Team Tongji (2012) \\
\hline UOW & DESICA & - & DESICA was used as a dehumidifier and integrated with the HVAC system. & Team UOW (2018) \\
\hline
\end{tabular}

608

${ }^{*}$ The product was listed in the take-off list of the project manual. 
612 Evaporative cooling is a technology that conditions the air by increasing its vapor content

613 (Cuce and Riffat, 2016). It has been used for indoor space cooling by a number of teams in the

614 SD competitions. It is noted that passive technologies such as using a green wall or a water

615 pond for evaporative cooling were not considered as evaporative cooling herein. The

616 evaporative cooling devices used in the SD competitions can be categorized into two types

617 including direct evaporative cooling and indirect evaporative cooling. In the direct ones, the

618 air to be supplied to the house directly contacts with water and was cooled by the evaporation

619 of the water. However, in indirect evaporative cooling systems, secondary air flow was cooled

620 using the same way as that used in direct evaporative cooling. The air to be supplied to the

621 house was cooled in the dry channel by sensible heat transfer through the plate which separates

622 the dry and wet channels.

623 Direct and indirect evaporative cooling systems were used by a few teams as part of their

624 space cooling systems. In the SD Europe 2010 competition, Team Wuppertal (Sánchez et al.,

625 2010) used an indirect evaporative cooler to condition the supply air. Team Nottingham

626 H.O.U.S.E. (Sánchez et al., 2010; Ford et al., 2012) developed a direct evaporative cooling

627 system by deploying nozzles at the top of the double height space of the house to generate a

628 mist of water in the SD Europe 2010 competition. The warm ambient air was drawn into the

629 house and cooled by the water evaporation, and the air distribution was achieved passively via

630 the downdraught effect. Team Unicode (2014) developed a water wall which was developed

631 using packing materials of Raschig rings in the SD Europe 2014 competition. The water was 
632 distributed from the top of the wall, and the outdoor air was cooled to reduce the air temperature

633 around the terrace of the house, which further decreased the heat gain of the living space from

634 ambient. A desiccant cooling system using an indirect evaporative cooler and a direct

635 evaporative cooler was developed by the RWTH Aachen University (2012) in the SD Europe

6362012 competition, as presented in Fig. 11. In this system, the outdoor air was first dehumidified

637 by a liquid desiccant dehumidifier and then cooled by an indirect evaporative cooler in which

638 the return air from the indoor space was used as the secondary air. A hydronic coil was used to

639 condition the supply air and a direct evaporative cooler was used to cool and humidify the

640 supply air. A similar indirect evaporative cooler to that used by the RWTH Aachen University

641

was also used by Team VIRTUe (2018) in the SD ME 2018 competition for conditioning the

642 fresh air, in which the return air was used as the secondary air and exhausted to the ambient.

643

644

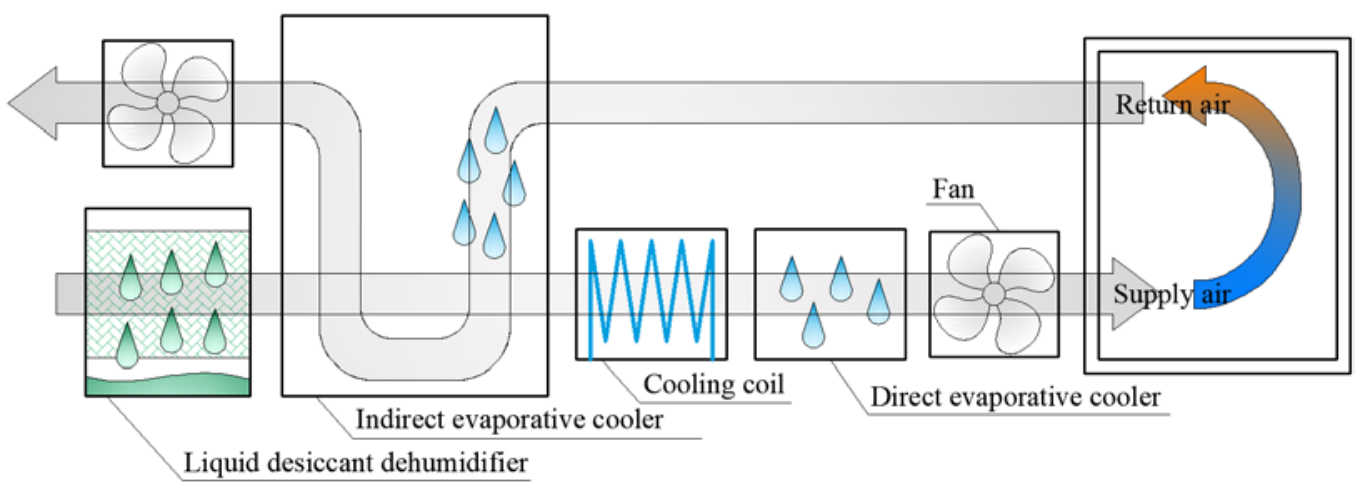

645 Fig. 11. A desiccant cooling system integrated with an indirect evaporative cooler and a direct evaporative cooler, modified from Team RWTH Aachen University (2012). 
cooler integrated with a motorized base with wheels, which means that the robot cooler could move in the SD house via the motorized base. The direct evaporative cooler was powered by a was designed to provide occupants with localized cooling in different places of the house.

654 It can be clearly seen that the application of evaporative cooling is still limited. In general, direct evaporative cooling could introduce extra moisture into the supply air, which is generally not favorable to the comfort conditions contest in the SD competitions. The indirect evaporative cooling could cool the supply air without increasing its humidity level while the configuration and structure of such coolers was more complex than that of the direct evaporative cooler. The evaporative cooling technology is more applicable for the SD competitions held under arid and moderate weather conditions.

661

\subsection{Advanced control strategies}

Control of HVAC systems is another critical issue to ensure that the HVAC systems are operated in an energy-efficient and cost-effective manner (Wang and Ma, 2008; Ma and Wang,

664 2009). However, the detailed description of the control strategies used for the HVAC systems

665 of the SD houses was generally not provided in the project manuals.

666 Only a few teams reported the use of advanced control strategies for their HVAC systems.

667 A model-based supervisory control strategy, for instance, was used by Team Maryland (2017)

668 to optimize the use of water, electricity and thermal energy, and carbon-based resources. The 669 mathematical models were developed to predict the solar radiation and the performance of the 670 PV panels, as well as to determine the heating and cooling load, indoor air temperature, and 
671 overall net electricity consumption and generation of the household. Based on the modelling

672 results, the sequence of the events that consume or generate significant amounts of energy,

673 water, and other resources was optimized by the control strategy, in order to maximize the

674 sustainability and economic goals of the SD house. Team Las Vegas (2017) used the monitoring

675 results of the indoor and outdoor conditions to forecast the spikes of cooling and heating load.

676 The forecast results allowed the control system to optimize the operation of the mechanical

677 system to maintain indoor thermal comfort.

678 Team UOW (Fiorentini et al., 2015; Fiorentini et al., 2017) developed a hybrid model

679 predictive control (HMPC) strategy to optimize the operation mode and control settings of the

680 solar-assisted HVAC system with integrated PVT collector and PCM TES unit, as presented in

681 Fig. 7. The HMPC was developed with two hierarchical levels, in which an HMPC controller

682 was used to select the operation mode of the HVAC system, and each operation mode was then

683 optimized at the low level. Team UOW (2018) integrated a model predictive control strategy

684 into the building management system. The strategy could forecast various factors over the next

68524 hours, e.g. weather conditions, power output of the PV panels, occupant's energy usage

686 habit. The forecast results could be used to optimize the operation of the HVAC system.

687 Advanced control strategies were only used in the SD houses in recent competitions. Such

688 technologies may play an important role in future SD competitions to optimize the operation

689 of the HVAC system through reliable load prediction, demand side management, rational use

690 of solar energy, and dynamic optimization of control settings.

691 5. Conclusions and discussions 
693 previous Solar Decathlon (SD) net-zero energy houses. Statistical analysis was implemented 694 for 212 SD houses from 13 SD competitions. Some conclusive remarks and recommendations 695 are as follows. and space cooling probably due to the fact that they have been widely used in residential buildings and showed good robustness in thermal comfort control, high energy efficiency, easy to implement and easy to control. ERVs/HRVs have also been frequently used in the SD houses as they could provide energy savings under a wide range of weather conditions.

- A number of the competition teams have explored the opportunities of using emerging technologies such as phase change materials and desiccant dehumidification to showcase innovations and reduce the electricity consumption for space heating and cooling. However, the real performance of such systems was not reported. seems that its popularity has been decreased in recent US competitions. When the PCMs are integrated with HVAC systems, advanced control such as model predictive control is generally required to optimize the charging and discharging processes to maximize the benefits of using PCMs.

- PCMs have been frequently used in the SD competitions held in Europe. However, it maximize the benefits of using PCMs.

- Solar thermal space heating has been frequently used in the SD competitions, especially in the competitions held in cold climates, while it was less preferred in the 
recent competitions held in the US. This technology was mainly used for pre-heating and/or as a supplementary heating system of conventional HVAC systems to reduce HVAC energy consumption. Recent studies showed that the simple payback period of solar thermal space heating systems could be 6.5 years under certain weather conditions (Agathokleous et al., 2019). Photovoltaic/thermal collectors could be a promising technology to generate electricity and thermal energy simultaneously.

- Desiccant dehumidification has been used by a number of the competition teams for better indoor humidity control and such systems in the SD competitions were mainly driven by solar thermal energy.

- The application of evaporative cooling in the SD houses is limited. This technology has been proven to be an effective solution for temperature control when it was integrated with desiccant dehumidification. However, the use of direct evaporative cooling may increase the latent load of the process air. The combination of evaporative cooling and desiccant dehumidification may be a feasible solution in the SD competitions for space cooling as it can be driven by low-grade thermal energy and can provide independent temperature and humidity control.

- Although several competition teams used absorption/adsorption systems for space cooling. However, such systems generally require relatively high-grade thermal energy (e.g. $80^{\circ} \mathrm{C}$ ) and high initial investment so they might not be a good technical option for the SD competitions. 

of using solar energy to take air conditioning off the grid. This will make great contribution to cleaner production.

737 heating and cooling with integrated thermal energy storage and dedicated model predictive control will play an essential role in future to provide low carbon emission heating and cooling for buildings and improve the productivity and wellbeing of occupants. It is believed that the SD competitions will continue to be an excellent platform to provide a live demonstration of the latest innovations in HVAC technologies.

Declarations of interest

744 None.

745

\section{References}

746 (e)co Team, 2012. Project manual and construction drawings of (e)co Team (Europe 2012). http://www.sdeurope.org/downloads/sde2012/ (accessed 05.03.2019).

748 Adhikari, R., Pipattanasomporn, M., Rahman, S., 2018. An algorithm for optimal management of aggregated HVAC power demand using smart thermostats. Applied Energy 217, 166-177.

751

Afram, A., Janabi-Sharifi, F., 2014. Theory and applications of HVAC control systems-A review of model predictive control (MPC). Building and Environment 72, 343-355. 2019. Building façade integrated solar thermal collectors for air heating: 

experimentation, modelling and applications. Applied Energy 239, 658-679.

Al-Alili, A., Hwang, Y., Radermacher, R., 2014. Review of solar thermal air conditioning technologies. International Journal of Refrigeration 39, 4-22.

Alemi. P., Loge, F., 2017. Energy efficiency measures in affordable zero net energy housing: A case study of the UC Davis 2015 Solar Decathlon home. Renewable Energy 101, 1242-1255.

Axell, M., 2015. Heat pump news: policy - The world is set to use more energy for cooling than for heating. IEA Heat Pump Centre Newsletter 2015 33(4), 6.

CEU Team Valencia, 2012. Project manual and construction drawings of CEU Team Valencia (Europe 2012). http://www.sdeurope.org/downloads/sde2012/ (accessed 05.03.2019).

Chua, K.J., Chou, S.K., Yang, W.M., Yan, J., 2013. Achieving better energy-efficient air conditioning - A review of technologies and strategies. Applied Energy 104, 87-104.

Cuce, P.M., Riffat, S., 2016. A state of the art review of evaporative cooling systems for building applications. Renewable and Sustainable Energy Reviews 54, 1240-1249.

Cui, B., Gao, D.C., Wang, S., Xue, X., 2015. Effectiveness and life-cycle cost-benefit analysis of active cold storages for building demand management for smart grid applications. Applied Energy 147, 523-535.

Cui, B., Gao, D.C., Xiao, F., Wang, S., 2017. Model-based optimal design of active cool thermal energy storage for maximal life-cycle cost saving from demand management in commercial buildings. Applied Energy 201, 382-396. 

Energy 86(9), 1376-1386.

Eicker. U., Dalibard. A., 2011. Photovoltaic-thermal collectors for night radiative cooling of buildings. Solar Energy 85(7), 1322-1335.

Fiorentini, M., Cooper, P., Ma, Z., 2015. Development and optimization of an innovative HVAC system with integrated PVT and PCM thermal storage for a net-zero energy retrofitted house. Energy and Buildings 94, 21-32.

Fiorentini, M., Wall, J., Ma, Z., Braslavsky, J.H., Cooper, P., 2017. Hybrid model predictive control of a residential HVAC system with on-site thermal energy generation and storage. Applied Energy 187, 465-479.

Ford, B., Wilson, R., Gillott, M., Ibraheem, O., Salmeron, J., Sanchez, F.J., 2012. Passive downdraught evaporative cooling: performance in a prototype house. Building Research

Fu, H.X., Liu, X.H., 2017. Review of the impact of liquid desiccant dehumidification on \& Information 40(3), 290-304.

792 Gennari, L., Péan, T., 2014. Conditioning of a plus-energy house using solar systems for both production of heating and nighttime radiative cooling [Master thesis report]. Technical University of Denmark. 
795 Giampieri, A., Ma, Z., Smallbone, A., Roskilly, A.P., 2018. Thermodynamics and economics 796 of liquid desiccants for heating, ventilation and air-conditioning-an overview. Applied Energy 220, 455-479.

798

Goldstein, E.A., Raman, A.P., Fan, S., 2017. Sub-ambient non-evaporative fluid cooling with 799 the sky. Nature Energy 2(9), 17143, 1-7.

800 Gomri, R., 2013. Simulation study on the performance of solar/natural gas absorption cooling 801 chillers. Energy Conversion and Management 65, 675-681.

802

Hanu, L., Kappels, T., Pollerberg, C., Knel, A., Jahangiri, P., 2012. Phase change slurries in panel cooling systems for buildings. In: International Conference on Energy Storage.

804 Lleida, Spain; 16-18 May 2012.

805

Hernández-Martínez, M.C., Bedoya C., García-Santos A., Neila J., Caamaño E., 2011. A 806 Architecture. Louvain-la-Neuve, Belgium; 13-15 July 2011.

809

810

811

Hu, B., Li, Y., Mu, B., Wang, S., Seem, J.E., Cao, F., 2016. Extremum seeking control for prototype from the Solar Decathlon Competition becomes an educational building in sustainable architecture. In: 27th International Conference on Passive and Low Energy

812 Huang, J., Tian, Z., Fan, J., 2019. A comprehensive analysis on development and transition of the solar thermal market in China with more than 70\% market share worldwide. Energy 174, 611-624.

815 Huang, B.J., Hou, T.F., Hsu, P.C., Lin, T.H., Chen, Y.T., Chen, C.W., Li, K., Lee, K.Y., 2016. 
817 Huang, P., Huang, G., Wang, Y., 2015. HVAC system design under peak load prediction uncertainty using multiple-criterion decision making technique. Energy and Buildings 91, 26-36.

Huang, S., Ma, Z., Wang, F., 2015. A multi-objective design optimization strategy for vertical ground heat exchangers. Energy and Buildings 87, 233-242.

822

Isaac, M., Van Vuuren, D.P., 2009. Modeling global residential sector energy demand for heating and air conditioning in the context of climate change. Energy Policy 37(2), 507521.

La Agencia Estatal de Meteorología (AEMET), 2019. Standard climate values. Madrid, Retiro. http://www.aemet.es/en/serviciosclimaticos/datosclimatologicos/valoresclimatologicos?l $=3195 \& \mathrm{k}=\mathrm{mad}$. (accessed 29.07.2019).

829 Lin, W., Ma, Z., Cooper, P., Sohel, M.I., Yang, L., 2016. Thermal performance investigation 830 and optimization of buildings with integrated phase change materials and solar 831 photovoltaic thermal collectors. Energy and Buildings 116, 562-573.

832 Ma, Z., Lin, W., Sohel, M.I., 2016. Nano-enhanced phase change materials for improved 833 building performance. Renewable and Sustainable Energy Reviews 58, 1256-1268.

834 Ma, Z., Wang, S., 2011. Supervisory and optimal control of central chiller plants using simplified adaptive models and genetic algorithm. Applied Energy 88(1), 198-211. 

water systems for practical and real-time applications. Building and Environment 44(6), 1188-1198.

Mardiana-Idayu, A., Riffat, S.B., 2012. Review on heat recovery technologies for building applications. Renewable and Sustainable Energy Reviews 16(2), 1241-1255.

Moon, S., Nahan, R., Warner, C., Wassmer, M., 2005. Solar Decathlon 2005 The Event in Review. https://www.solardecathlon.gov/past/2005/technical_report.html (accessed 05.03.2019).

844 O’Kelly, M., Walter, M.E., Rowland, J.R., 2015. Simulated hygrothermal performance of a 845 desiccant-assisted hybrid air/water conditioning system in a mixed humid climate under dynamic load. Energy and Buildings 86, 45-57.

847 PCM products Ltd., 2019. PCM products data sheets. http://www.pcmproducts.net/ (accessed 05.03.2019).

849 Pérez-Lombard, L., Ortiz, J., Pout, C., 2008. A review on buildings energy consumption $850 \quad$ information. Energy and buildings, 40(3), 394-398.

851 Raman, A.P., Anoma, M.A., Zhu, L., Rephaeli, E., Fan, S., 2014. Passive radiative cooling 852 below ambient air temperature under direct sunlight. Nature 515(7528), 540-544.

853 Real, A., García, V., Domenech, L., Renau, J., Montés, N., Sánchez, F., 2014. Improvement 854 of a heat pump based HVAC system with PCM thermal storage for cold accumulation 855 and heat dissipation. Energy and Buildings 83, 108-116. 
Rehman, T.U., Ali, H.M., Janjua, M.M., Sajjad, U., Yan, W.M., 2019. A critical review on heat transfer augmentation of phase change materials embedded with porous materials/foams. International Journal of Heat and Mass Transfer 135, 649-673.

Ren, H., Ma, Z., Lin, W., Wang, S., Li, W., 2019a. Optimal design and size of a desiccant cooling system with onsite energy generation and thermal storage using a multilayer perceptron neural network and a genetic algorithm. Energy Conversion and Management 180, 598-608.

Ren, H., Ma, Z., Gschwander, S., 2019b. Characterisation and evaluation of a new phase change enhanced working solution for liquid desiccant cooling systems. Applied Thermal Engineering 150, 1197-1205.

RGEES, 2019. Phase Change Material PCM 29P product data sheet. https://rgees.com/product_PCM29P.php (accessed 05.03.2019).

Rodriguez-Ubinas, E., Montero, C., Porteros, M., Vega, S., Navarro, I., Castillo-Cagigal, M., Matallanas, E., Gutiérrez, A., 2014. Passive design strategies and performance of Net Energy Plus Houses. Energy and Buildings 83, 10-22.

871 Rodríguez-Ubiñas, E., Ruíz-Valero, L., Sánchez, S.V., González, F.N., 2011. Latent heat 872 thermal energy storage systems in lightweight construction: review of PCM applications in Solar Decathlon houses. WIT Transactions on Ecology and the Environment 150, 05.03.2019). 
877 Sahlot, M., Riffat, S.B., 2016. Desiccant cooling systems: a review. International Journal of $878 \quad$ Low-Carbon Technologies 11(4), 489-505.

879 Sánchez, S.V., Murcutt, G., Ernst, W., Mumovic, D., Baurier, F.P.-A., Koleeny, J., et al., 2010.

880 Solar Decathlon Europe 2010 Towards energy efficient buildings.

881 http://www.sdeurope.org/el-libro-de-las-casas-participantes-en-sdeurope-2010-con-

$882 \quad$ 10action (accessed 02.04.2018).

883 Shirazi, A., Taylor, R.A., Morrison, G.L., White, S.D., 2018. Solar-powered absorption

884 chillers: A comprehensive and critical review. Energy Conversion and Management 171, $885 \quad 59-81$

886 Solar Decathlon China, 2018. Official website of Solar Decathlon China Competitions.

887 http://www.sdchina.org.cn/ (accessed 05.03.2019).

888 Solar Decathlon Europe, 2012. Official website of Solar Decathlon Europe Competitions 889 (2010-2012). http://www.sdeurope.org/downloads/sde2012/ (accessed 02.04.2018)

890 Solar Decathlon Europe, 2014. Official website of Solar Decathlon Europe Competitions

891 (2014). http://www.solardecathlon2014.fr (accessed 02.04.2018).

892 Solar Decathlon Latin America \& Caribbean, 2015. Official website of Solar Decathlon Latin 893 America \& Caribbean Competitions. http://solardecathlonlac.com/ (accessed $894 \quad$ 05.03.2019).

895 Solar Decathlon Middle East, 2018. Official website of Solar Decathlon Middle East

896 Competitions. https://www.solardecathlonme.com/ (accessed 05.03.2019).

897 Solar Decathlon US, 2017. Official website of Solar Decathlon US Competitions. 
899 Sun, Y., Wang, S., Xiao, F., Gao, D., 2013. Peak load shifting control using different cold

900 thermal energy storage facilities in commercial buildings: A review. Energy Conversion

$901 \quad$ and Management 71, 101-114.

902 Team Alabama, 2017. Project manual, construction drawings, and innovation narratives of

903 Team Alabama (US 2017). https://www.solardecathlon.gov/2017/competition-team-

$904 \quad$ alabama.html (accessed 05.03.2019).

905 Team Alberta, 2013. Project manual and construction drawings of Team Alberta (US 2013).

906 https://www.solardecathlon.gov/past/2013/technical_resources.html (accessed

$907 \quad$ 05.03.2019).

908 Team Appalachian State, 2011. Project manual and construction drawings of Team

$909 \quad$ Appalachian State (US 2011).

910 https://www.solardecathlon.gov/past/2011/technical_resources.html (accessed

$911 \quad$ 05.03.2019).

912 Team Aquitaine Bordeaux Campus, 2012. Project manual and construction drawings of Team

913 Aquitaine Bordeaux Campus (Europe 2012).

914 http://www.sdeurope.org/downloads/sde2012/ (accessed 05.03.2019).

915 Team AZ State / New Mexico, 2013. Project manual and construction drawings of Team AZ

916 State / New Mexico (US 2013).

917 https://www.solardecathlon.gov/past/2013/technical_resources.html (accessed

$918 \quad$ 05.03.2019). 
919 Team BaityKool, 2018. Project manual and construction drawings of Team BaityKool (ME

920 2018). https://www.solardecathlonme.com/teams/team-baitykool (accessed 01.06.2019).

921 Team Chiba University, 2014. Project manual and construction drawings of Team Chiba

922 University (Europe 2014). http://www.solardecathlon2014.fr/en/documentation

$923 \quad$ (accessed 05.03.2019).

924 Team Cincinnati, 2007. Project manual and construction drawings of Team Cincinnati (US 925 2007). https://www.solardecathlon.gov/past/2007/technical_resources.html (accessed

$926 \quad$ 05.03.2019).

927 Team Colorado, 2007a. Project manual and construction drawings of Team Colorado (US

928 2007). https://www.solardecathlon.gov/past/2007/technical_resources.html (accessed

$929 \quad$ 05.03.2019).

930 Team Colorado, 2007b. CORE User Manual. http://solar.colorado.edu/concept/index.html

$931 \quad$ (accessed 05.03.2019).

932 Team Darmstadt, 2007. Project manual and construction drawings of Team Darmstadt (US

933 2007). https://www.solardecathlon.gov/past/2007/technical_resources.html (accessed

$934 \quad$ 05.03.2019).

935 Team DTU, 2014. Project manual and construction drawings of Team DTU (Europe 2014).

936 http://www.solardecathlon2014.fr/en/documentation (accessed 05.03.2019).

937 Team ECOLAR, 2012. Project manual and construction drawings of Team ECOLAR (Europe

938 2012). http://www.sdeurope.org/downloads/sde2012/ (accessed 05.03.2019). 
939 Team équipe VIA-UJI, 2014. Project manual and construction drawings of Team équipe VIA-

940 UJI (Europe 2014). http://www.solardecathlon2014.fr/en/documentation (accessed

$941 \quad$ 05.03.2019).

942 Team FENIX, 2014. Project manual and construction drawings of Team FENIX (Europe

943 2014). http://www.solardecathlon2014.fr/en/documentation (accessed 05.03.2019).

944 Team Florida, 2011. Project manual and construction drawings of Team Florida (US 2011).

945 https://www.solardecathlon.gov/past/2011/technical_resources.html (accessed

$946 \quad$ 05.03.2019).

947 Team Germany, 2009. Project manual and construction drawings of Team Germany (US

948 2009). https://www.solardecathlon.gov/past/2009/technical_resources.html (accessed

$949 \quad$ 05.03.2019).

950 Team Iowa State, 2009. Project manual and construction drawings of Team Iowa State (US

951 2009). https://www.solardecathlon.gov/past/2009/technical_resources.html (accessed

$952 \quad$ 05.03.2019).

953 Team Israel, 2013. Project website of Team Israel (China 2013). http://www.israel-

$954 \quad$ sd2013.com/?lang=en (accessed 05.03.2019).

955 Team Las Vegas, 2017. Project manual and construction drawings of Team Las Vegas (US

956 2017). https://www.solardecathlon.gov/2017/competition-team-las-vegas.html (accessed

$957 \quad$ 05.03.2019). 
958 Team Maryland, 2007a. Project manual and construction drawings of Team Maryland (US 2007). https://www.solardecathlon.gov/past/2007/technical_resources.html (accessed

960 05.03.2019).

961 Team Maryland, 2007b. Project website of Team Maryland (US 2007).

962 http://2007.solarteam.org/page.php?id=641 (accessed 05.03.2019).

963 Team Maryland, 2011. Project manual and construction drawings of Team Maryland (US 2011). https://www.solardecathlon.gov/past/2011/technical_resources.html (accessed 05.03.2019).

Team Maryland, 2017. Project manual, construction drawings, and engineering and innovation narratives of Team Maryland (US 2017).

968 https://www.solardecathlon.gov/2017/competition-team-maryland.html (accessed 26.07.2019).

970 Team Mexico UNAM, 2014. Project manual and construction drawings of Team Mexico

971 UNAM (Europe 2014). http://www.solardecathlon2014.fr/en/documentation (accessed $972 \quad$ 05.03.2019).

973 Team Minnesota, 2009. Project manual and construction drawings of Team Minnesota (US 974 2009). https://www.solardecathlon.gov/past/2009/technical_resources.html (accessed $975 \quad$ 05.03.2019).

976 Team New York, 2011. Project manual and construction drawings of Team New York (US 977 2011). https://www.solardecathlon.gov/past/2011/technical_resources.html (accessed $978 \quad$ 05.03.2019). 
979 Team North Carolina, 2013. Project manual and construction drawings of Team North

980 Carolina (US 2013). https://www.solardecathlon.gov/past/2013/technical_resources.html

$981 \quad$ (accessed 05.03.2019).

982 Team Odooproject, 2012. Project manual and construction drawings of Team Odooproject

983 (Europe 2012). http://www.sdeurope.org/downloads/sde2012/ (accessed 05.03.2019).

984 Team Ohio State, 2011. Project manual and construction drawings of Team Ohio State (US

985 2011). https://www.solardecathlon.gov/past/2011/technical_resources.html (accessed

$986 \quad$ 05.03.2019).

987 Team Ontario/BC, 2009. Project manual and construction drawings of Team Ontario/BC (US

988 2009). https://www.solardecathlon.gov/past/2009/technical_resources.html (accessed

$989 \quad$ 05.03.2019).

990 Team ORA, 2018. Jury report of Team ORA (ME 2018).

991 https://www.solardecathlonme.com/teams/team-ora (accessed 01.06.2019).

992 Team Penn State, 2007. Project manual, construction drawings, and engineering handout of

993 Team Penn State (US 2007).

994 https://www.solardecathlon.gov/past/2007/technical_resources.html (accessed

$995 \quad$ 05.03.2019).

996 Team Prêt-à-Loger, 2014. Project manual and construction drawings of Team Prêt-à-Loger

997 (Europe 2014). http://www.solardecathlon2014.fr/en/documentation (accessed

$998 \quad$ 05.03.2019). 
999 Team Réciprocité, 2014. Project manual and construction drawings of Team Réciprocité

$1000 \quad$ (Europe 2014). http://www.solardecathlon2014.fr/en/documentation (accessed

$1001 \quad$ 05.03.2019).

1002 Team Rhône-Alpes, 2012. Project manual and construction drawings of Team Rhône-Alpes

1003 (Europe 2012). http://www.sdeurope.org/downloads/sde2012/ (accessed 05.03.2019).

1004 Team Rooftop, 2014. Project manual and construction drawings of Team Rooftop (Europe

1005 2014). http://www.solardecathlon2014.fr/en/documentation (accessed 05.03.2019).

1006 Team RWTH Aachen University, 2012. Project manual and construction drawings of Team

1007 RWTH Aachen University (Europe 2012). http://www.sdeurope.org/downloads/sde2012/

$1008 \quad$ (accessed 05.03.2019).

1009 Team Santa Clara, 2007. Project manual and construction drawings of Team Santa Clara (US

1010 2007). https://www.solardecathlon.gov/past/2007/technical_resources.html (accessed

$1011 \quad$ 05.03.2019).

1012 Team Solar Cal Poly, 2015. Project manual and construction drawings of Team Solar Cal

1013 Poly (US 2015). https://www.solardecathlon.gov/2015/competition-team-cal-poly.html

$1014 \quad$ (accessed 05.03.2019).

1015

1016 Team Stevens, 2013a. Project manual and construction drawings of Team Stevens (US 2013).

1017 https://www.solardecathlon.gov/past/2013/technical_resources.html (accessed

$1018 \quad$ 05.03.2019).

1019 Team Stevens, 2013b. Project website of Team Stevens (US 2013). 

https://web.stevens.edu/sd2013/ (accessed 05.03.2019).

1021 Team TDIS, 2018. Project manual and construction drawings of Team TDIS (ME 2018).

1022 https://www.solardecathlonme.com/teams/team-tdis (accessed 01.06.2019).

1023 Team TEC, 2014. Project manual and construction drawings of Team TEC (Europe 2014).

1024 http://www.solardecathlon2014.fr/en/documentation (accessed 05.03.2019).

1025 Team Texas, 2007. Project manual and construction drawings of Team Texas (US 2007).

1026 https://www.solardecathlon.gov/past/2007/technical_resources.html (accessed

$1027 \quad$ 05.03.2019).

1028 Team Tongji, 2012. Project manual and construction drawings of Team Tongji (Europe 2012).

1029 http://www.sdeurope.org/downloads/sde2012/ (accessed 05.03.2019).

1030 Team UC Davis, 2015. Project manual and construction drawings of Team UC Davis (US

1031 2015). https://www.solardecathlon.gov/2015/competition-team-uc-davis.html (accessed

$1032 \quad$ 05.03.2019).

1033 Team Unicode, 2014. Project manual and construction drawings of Team Unicode (Europe

1034 2014). http://www.solardecathlon2014.fr/en/documentation (accessed 05.03.2019).

1035 Team UOW, 2018. Project manual and construction drawings of Team UOW (ME 2018).

1036 https://www.solardecathlonme.com/teams/team-uow (accessed 01.06.2019).

1037 Team Virginia Tech, 2009. Project manual and construction drawings of Team Virginia Tech

1038 (US 2009). https://www.solardecathlon.gov/past/2009/technical_resources.html

$1039 \quad$ (accessed 05.03.2019). 
1040 Team Virginia Tech, 2018. Project manual and construction drawings of Team Virginia Tech (ME 2018). https://www.solardecathlonme.com/teams/team-virginia-tech (accessed 01.06.2019).

Team VIRTUe, 2018. Project manual and construction drawings of Team VIRTUe (ME 2018). https://www.solardecathlonme.com/teams/virtue (accessed 01.06.2019) (accessed 01.06.2019).

Team WASH U - ST. LOUIS, 2017. Project manual, and construction drawings of Team WASH U - ST. LOUIS (US 2017). https://www.solardecathlon.gov/2017/competitionteam-washington-university.html (accessed 05.03.2019).

U.S. DOE (Department of Energy), 2005. 2005 Solar Decathlon (Competition Program). https://www.nrel.gov/docs/fy06osti/37905.pdf (accessed 05.03.2018).

1051

1052

Wang, S., Ma, Z., 2008. Supervisory and optimal control of building HVAC systems: A

Wang, Z., Wang, F., Liu, J., Ma, Z., Han, E., Song, M., 2017. Field test and numerical investigation on the heat transfer characteristics and optimal design of the heat review. HVAC\&R Research 14(1), 3-32.

Xia, L., Ma, Z., Kokogiannakis, G., Wang, Z., Wang, S., 2018. A model-based design optimization strategy for ground source heat pump systems with integrated photovoltaic thermal collectors. Applied Energy 214, 178-190.

1060 Xiao, Y., Cao, Z., Zhong, G., 2015. Net-zero energy building Econcave. South China 

University of Technology Press, Guangzhou.

1062 Zeyghami, M., Goswami, D.Y., Stefanakos, E., 2018. A review of clear sky radiative cooling 1063 developments and applications in renewable power systems and passive building 1064 cooling. Solar Energy Materials and Solar Cells 178, 115-128.

1065 Zhao, B., Hu, M., Ao, X., Chen, N., Pei, G., 2019. Radiative cooling: A review of 1066 fundamentals, materials, applications, and prospects. Applied Energy 236, 489-513. 